\title{
LO NACIONAL COMO PROYEGTO Y REALIZACIÓN EN LA DANZA MEXICANA DE HOY
}

\section{Alberto Dallat}

México es un país de danzantes. Desde hace siglos son notables las prácticas todas de este arte. También las significaciones que han adquirido las obras y las actitudes dancísticas de los mexicanos. Antes de la llegada de los españoles, todas las culturas que floreciexon en el territorio nacional practicaban la danza, una danza de naturaleza ritual, sagrada, que ponía énfasis en la perfección formal y técnica de coreografías, pasos e interpretaciones, toda vez que constituían medios de vinculación con las distintas deidades y fuerzas que vigilaban al mismo tiempo la vida terrenal y la vida no terrenal de los indígenas.

Tanto los cronistas de la Conquista como los historiadores subsecuentes han detectado pruebas importantes del florecimiento del arte de la danza en el mundo prehispánico. Asimismo, se han referido a los sistemas de organización y de enseñanza a través de los cuales los indígenas de las distintas culturas y civilizaciones de México "socializaban", imponian y desarrollaban las prácticas dancísticas. Sahagún se refiere al telpochcalli o escuela de los jóvenes y nobles guerreros de la siguiente manera:

tenian costumbre cada día, a la puesta del sol, (que) ponían lumbre en la casa de cuicacalco los mancebos, y comenzaban a bailar y danzar todos, hasta pasada la media noche; y no tenín otras mantas sino aquellas mantas que se llaman chalcaóyatl que andaban casi desnudos; y después de haber bailado todos iban a las casas de telpochcalli a dormir, en cada barrio, y así lo hacían cada noche; y los que eran amancebados íbanse a dormir con sus amigas. ${ }^{1}$

También expresa la rigidez de las normas que imperaban en dicho establecimiento educativo:

... y andando en el baile, si alguno de los cantores hacía falta en el canto, o si los que tañían el teponaztli y atambor faltaban en el tañer, o si los que guían erraban en los meneos y contenencias del

1 Samuel Martí, Canto, danza y música precortesianas, México, Fondo de Cultura Económica, 1961, p. 170 . 
baile, luego el señor les mandaba prender y otro día los mandaba matar. ${ }^{2}$

Puede uno imaginarse que la existencia de este tipo de instituciones requería de una infraestructura material, técnica y social adecuada. Por las referencias documentales podemos inferir que estos lugares de danza, canto y, por así decirlo, "diseño ritual" propiciaban hasta cierto punto la erradicación de las diferencias sociales y gremiales. Eran también instalaciones en donde se difundían la moral y la ideología de los estratos gobernantes toda vez que de alli emanaban las "apropiadas" conductas y actitudes de los jóvenes. Por último, eran sitios en los que motu proprio o por definición magisterial de vocaciones, los mancebos "después de ya criados y enseñados en los exercicios", pasaban a realizar las actividades que les correspondía desempeñar en la sociedad mexica.

Destos niños auia cassa particular como escuela ó pupilage donde hauia gran numero de muchachos los quales tenian ayos y maestros que les enseñauan y yndustriaban en buenos y loables exercicios y costumbres a ser bien criados a tener reverencia a los mayores a servir a obedecer dandoles documentos como hauian de servir a los señores para cauer entre ellos y sauelles ser agradables, alli los ensem ñauan a cantar a dançar y a otras mill sotileças. También los yndustriaban (sic) exercicios de guerra a tirar una flecha apuntería a tirar una fisga o baras tostadas con amientos a mandar bien una rodela y espada haciendolos dormir mal y comer peor para que desde niños supiesen de trauajos y no se criasen con regalo. ${ }^{3}$

Los llamados a consagrarse a las acciones y actividades estricta y profesionalmente religiosas ingresaban en el tlamazcalli ("casa de hombre perfecto") en donde profesores especialistas los familiarizaban con ritos más elaborados y tareas de indole más profunda y responsable. ${ }^{4}$

Resulta comprensible la enorme importancia que los indígenas prehispánicos concedían al ejercicio dancístico, toda vez que en sus ceremonias se vinculaban unívocamente lo religioso y lo estético. Tanto el diseño coreográfico como la interpretación, a causa de esta vinculación teológico-estética, requería de una enorme habilidad organiza-

2 Ibid.

3 Fray Diego Durán, Ritos y fiestas de los antiguos mexicanos, edición facsimi. lar de la de Chavero de 1880, Ed.. Inovación, México, 1980, p. 108.

4 Ibid., p. 109 , 
tiva y de un despliegue de efectividad y talento sólo comparable a las ceremonias impresionantes de auge histórico, político y religioso de muy contadas situaciones de la cultura occidental:

... salian luego todos aquellos mancebos y aquellas moças asi aderecados como arriba dejo dicho de guirnaldas y sartales á los cuellos de maiz reventados puesto en orden y en rengleras los unos frontero de los otros bailauan y cantauan y al son de un atanbor que les tañian cantores en loor de aquel ydolo y de la solenidad á cuyo canto todos los señores y biejos y gente principal respondian haçiendo su rueda y bayle como lo tienen de costumbre teniendo á los mozos y moças en medio a cuyo espetaculo concurria toda la ciudad. ${ }^{5}$

Factor fundamental para la creación y recreación de la danza indígena fue y sigue siendo el espacio. El espacio resulta tan importante para la danza como lo es para la arquitectura, la escultura y la pintura mural, actividades artísticas que desarrollaron plena y profundamente las culturas del México antiguo. Tal como podemos apreciarlo en los códices y murales, la creatividad coreográfica era afecta a los grandes conjuntos, a las proezas de alcances extraordinarios, al colorido de coros y multitudes y a las ceremonias que implican la ritualización participativa del pueblo. Los indigenas eran sumamente aptos para conformar una simbología operativa y su capacidad de representación alcanzó el extremo de trazar una línea divisoria entre los hábitos y costumbres de la vida cotidiana, por una parte, y los códigos y usanzas religiosos y guerreros, por la otra. Esta circunstancia y esta actitud trajeron consigo, dentro de la actividad colectiva de cada cultura, de cada nación indigena, el desarrollo de formas simbólicas específicas que alcanzaron su plenitud y su plena vigencia en la abstracción. De esta manera una sola línea, el trazo preciso y firme sobre la piedra, la acentuación de los rasgos primordiales de rostros y cuerpos, la decantación de la expresividad, el manejo del colorido y de la composición, y la excepcional sintesis lograda en ceremonias y atavíos señalan un desenvolvimiento artístico notable que aun en la época contemporánea podría competir en pureza, habilidad, convergencia representacional, exactitud y limpieza formales con los más dstacados productos de las es. cuelas abstractas incluidas en los distintos campos y manifestaciones del arte. Los jeroglíficos mismos indican esta vital capacidad para ma-

5 Ibid., p. 95. 
terializar, representar y hacer trascendentes el espacio, el tiempo, la materia y el sentido mismo de los fenómenos de la naturaleza.

En sus ceremonias y danzas, los antiguos pobladores del país involucrarían la ligereza de los cuerpos, la expresividad de los atuendos, el respeto por las dignidades sociales y religiosas y los recursos físicos desarrollados por medio de sus artes marciales y religiosas. También contarían en las aptitudes del cuerpo sus nociones bien delimitadas de la división social del trabajo y de las ocupaciones.

... los que danzaban unos iban asidos por las manos, otros echaban los brazos a su compañero, abrazándole por la cintura, todos llevaban un compás en el azar del pie y en el achar del paso adelante, y en el volver atrás y en el hacer de las vueltas; danzaban por entre los candeleros o fogones, haciendo contrapeso entre ellos, danzaban hasta bien noche $[y]$ cesaban a la hora de las nueve de la noche. En cesando el que tañía el atambor, y teponaztli, luego todos se paraban y luego comenzaban de ir a sus casas... ${ }^{6}$

Aunque durante sus ceremonias se especificaron solemnemente las categorías sociales para establecer diferencias univocas entre nobles y plebeyos, la danza era para los indigenas un ejercicio sagrado que hacía olvidar, aun por un momento, la silenciosa opresión y los sufrimientos múltiples de la gente. Así,

... los gentiles hombres que iban bailando iban delante y no llevaban aquel compás de los areitos, sino el compás de las danzas de Castilla la Vieja, que van unos trabados de otros y culebreando. También los ministros de los ídolos iban bailando y danzando al son del mismo teponaztti, iban tañendo sus cornetas y sus caracoles; y cuando los sátrapas hacían vuelta delante de la diosa Xillonen, sembraban incienso por donde iba a pasar...7

En la actualidad sobreviven muchas formas prehispánicas aun en las modalidades populares y espontáneas de la danza mexicana. Asimismo, no obstante el paso del tiempo, las coreografías de aquella época han llegado hasta nosotros aderezadas con la actitud religiosa hispánica y con un sabor indígena que ni la tradición ni el paso del tiempo ni la incorporación de nuevos gustos y formas han logrado erradicar.

6 Fray Bernardino de Sahagún, Historia general de las cosas de Nueva España (I, II, c 27), citado por Samuel Martí, Canto, danza y música precortesianos, México, Fondo de Cultura Económica, 1961, p. 187.

7 Ibid., p. 189. 
No obstante la multiplicidad de rutinas coreográficas y códigos que se han ido incorporando a todas las modalidades y géneros dancísticos de México, parece sobrevivir siempre un elemento que tiende a buscar la síntesis lograda, en el cenit de su desarrollo, por las culturas prer hispánicas. A veces es posible explicar este prurito de abstracción, este anbelo de "forma decantada", esta simbolización extrema gracias a la influencia directa de las manifestaciones prehispánicas que en distintas épocas de la historia (y como una especie de subterráneo destino) aflora a la realidad artística mexicana con sus impresionantes muestras. En general, se trata de discursos y afirmaciones visuales que se revelan en una magnitud cierta e inconfundible. Su caracterización no da lugar a confusiones: son elementos mexicanos por antonomasia, evidentemente inclinados hacia esa economía de medios expresivos que, a la manera de la usanza prehispánica, denote rasgos y naturaleza en un solo aliento de la voz, en un solo trazo, de una sola vez. En ciertos productos artísticos esta enorme expresividad abstracta imperecedera hace aflorar interpretaciones enteras y abre las puertas a la especulación en torno a una misteriosa aparición de los mitos, de las culturas y de la historia prehispánica misma. De esta manera, lo elemental deviene exposición de mundos y submundos enteros, de universos mucho más complicados de lo que a simple y primera vista es posible apreciar, calificar o bien clasificar.

En estas limitaciones para la ubicación certera de una cultura sumamente compleja radica la dificultad de ofrecer afirmaciones contundentes y por ello se ha hablado y seguirá hablándose de la "identidad nacional". En el plano del arte esta búsqueda de una definición exacta mediante parámetros "occidentales" conocidos, presiona sobre ciertos aspectos de las manifestaciones prehispánicas que no pueden ser explicadas de una vez por todas y mucho menos de una manera superficial. En lo que a las danzas prehispánicas se refiere, puede observarse una especie de "erosión" o paso del tiempo. Es obvio que no hemos logrado reconstruir las piezas originales ya que se han extinguido algunas de sus características básicas. Las danzas han sufrido la pérdida paulatina de, por ejemplo, los movimientos reiterativos de las piernas y de las plantas de los pies, los rítmicos y repetidos golpes sobre el suelo (que a la vez parecen extraer y reproducir lós ruidos del interior de la Tierra, tal como sucede en el flamenco y, aunque superficialmente, en el tap dancing), las prolongadísimas sesiones dancístico-rituales, las 
invocaciones del cuerpo mediante movimientos angulares, no curvos. Todos estos códigos y hábitos coreográficos han ido desapareciendo a lo largo del tiempo pero aun hoy surgen inesperadamente apenas un coreógrafo contemporáneo descubre en la reproducción de la música indígena ciertos visos de singularidad rítmica y de finura total. En la danza contemporánea mexicana ha ocurrido esporádicamente lo mismo que en la pintura mural: el producto actual "resuelve" ciertos problemas formales mediante una indudable y a veces inigualable suma de elementos y recursos, subrayando la expresividad del acto o de la figura y por así decirlo revelando de nueva cuenta un "estilo" que nuestros ancestros indígenas manejaban diestramente.

Las inclinaciones alegóricas de los conquistadores españoles sustituyeron a los actos rituales, a las imponentes ceremonias dancísticas de los habitantes prehispánicos del país. Tras la paulatina "teatralización" de la danza, la efervescencia y las habilidades del cuerpo se trasladaron poco a poco a las modalidades espontáneas y populares. Durante la Colonia, las entusiastas explosiones dancísticas en comunidades indígenas, en suburbios, en poblaciones alejadas de los centros religiosos adquieren visos diabólicos y pecaminosos. Las acciones didácticas de los siglos xvi y xvir, un poco más tarde tendrían que ser vigiladas y reglamentadas por las autoridades civiles y eclesiásticas ya que eran óbice y daban pie al desbordamiento de ciertas pasiones y actitudes carnales. Resultó más tranquila la incorporación de los ya establecidos bailables europeos a los salones de los españoles y criollos. Resultó más aceptable la vigilada enhebración y el relativo machihembrado de las modalidades populares españolas y locales en fiestas, saraos y carnavales. Naturalmente, hasta cier to grado de recreación y hasta cierto grado de regocijo. Las constantes visitas de compañías teatrales, dancísticas y operísticas, sobre todo a la capital de la Nueva España, no sólo imponían en el país los símbolos y los mensajes de las autoridades centrales; también "retenían", limitaban las ambiciones recreativas de una danza más libre y "natural" para los pobladores indígenas e incluso para los mestizos. Con todo, estos últimos, siempre duchos y habilidosos, crearon sus propias formas de expresión dancistica a partir de lo que veían en los tablados y los escenarios, al grado de que muchas modalidades europeas de danza popular vinieron a encontrar su más notable y sabrosa expresividad en América y especificamente en la Nueva España.

Sin embargo, la Conquista española de ninguna manera acabó con 
DOI: http://dx.doi.org/10.22201/iie.18703062e.1983.52.1181

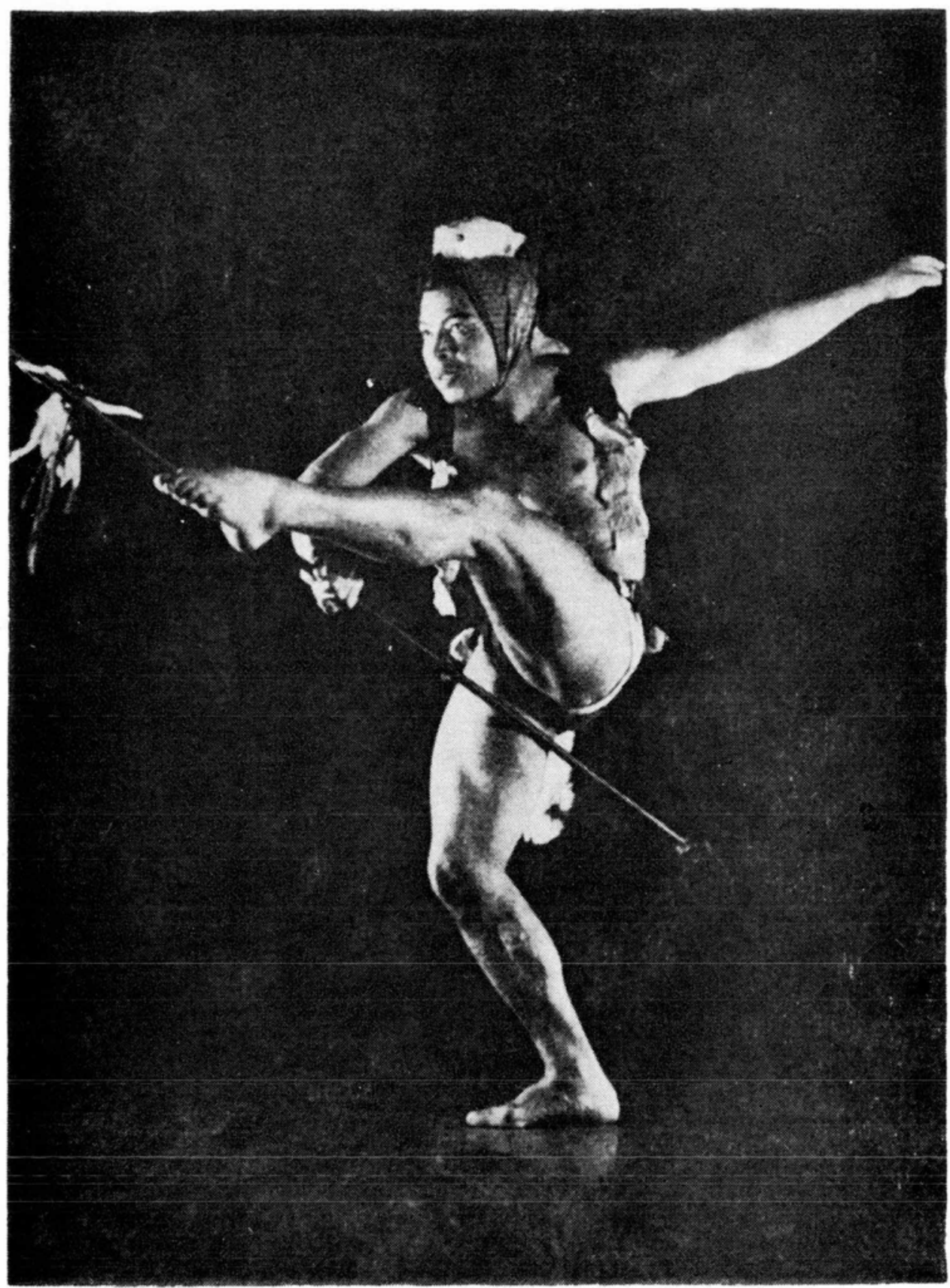

Figura 1. José Mata en Danzas de hechiceria de Guillermina Bravo. 1961. 


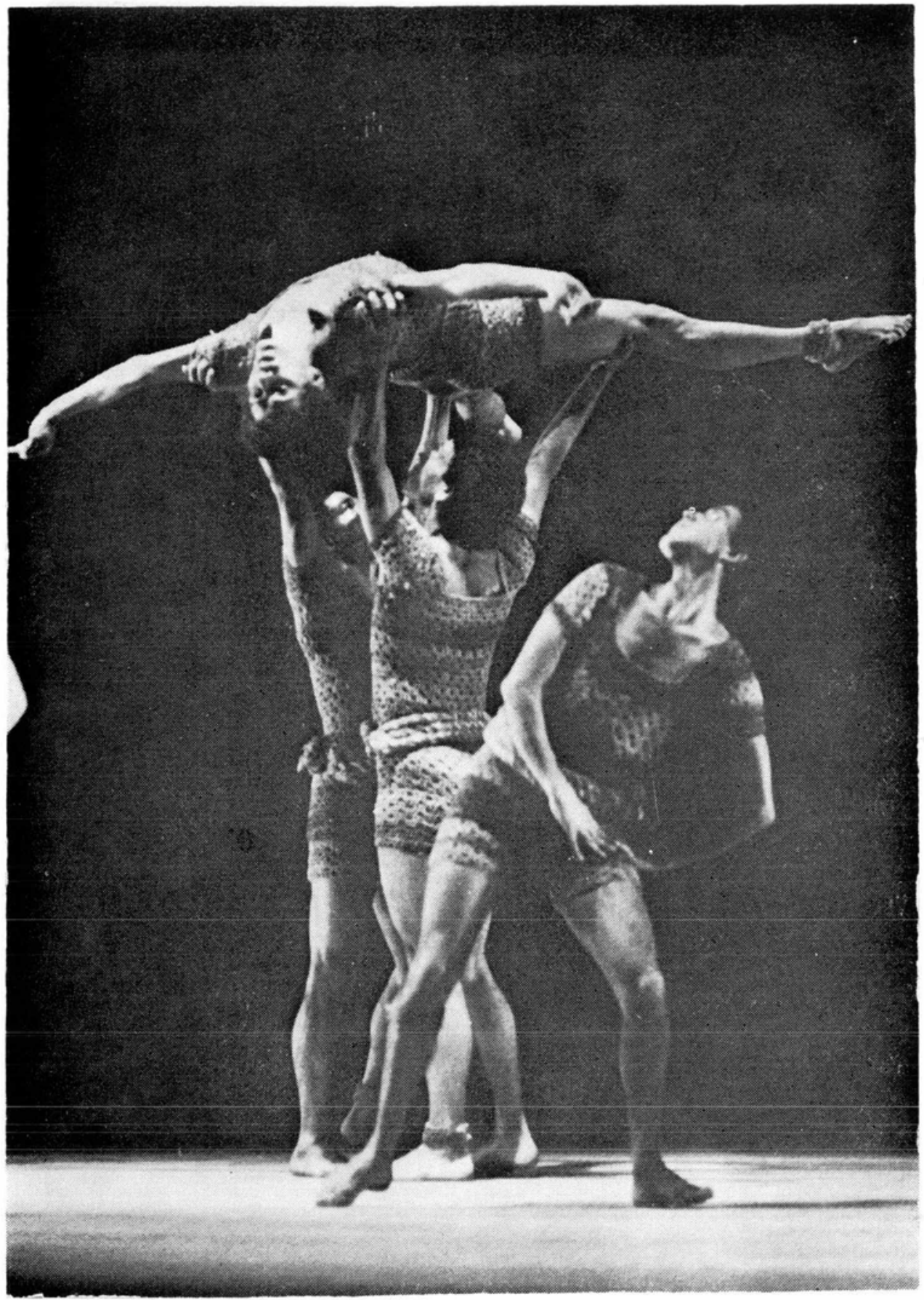

Figura 2. Juego de pelota de Guillermina Bravo. 1968. Foto: Renzo Góstoli. 


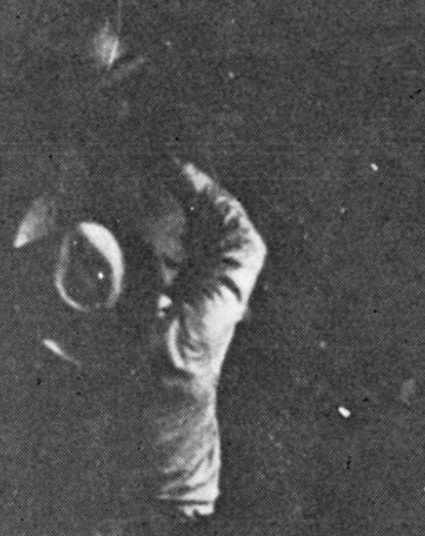

Figura 3. Carlos Gaona y Aurea Turner en Braceros de Guillermina Bravo. 1957. 
DOI: http://dx.doi.org/10.22201/iie.18703062e.1983.52.1181

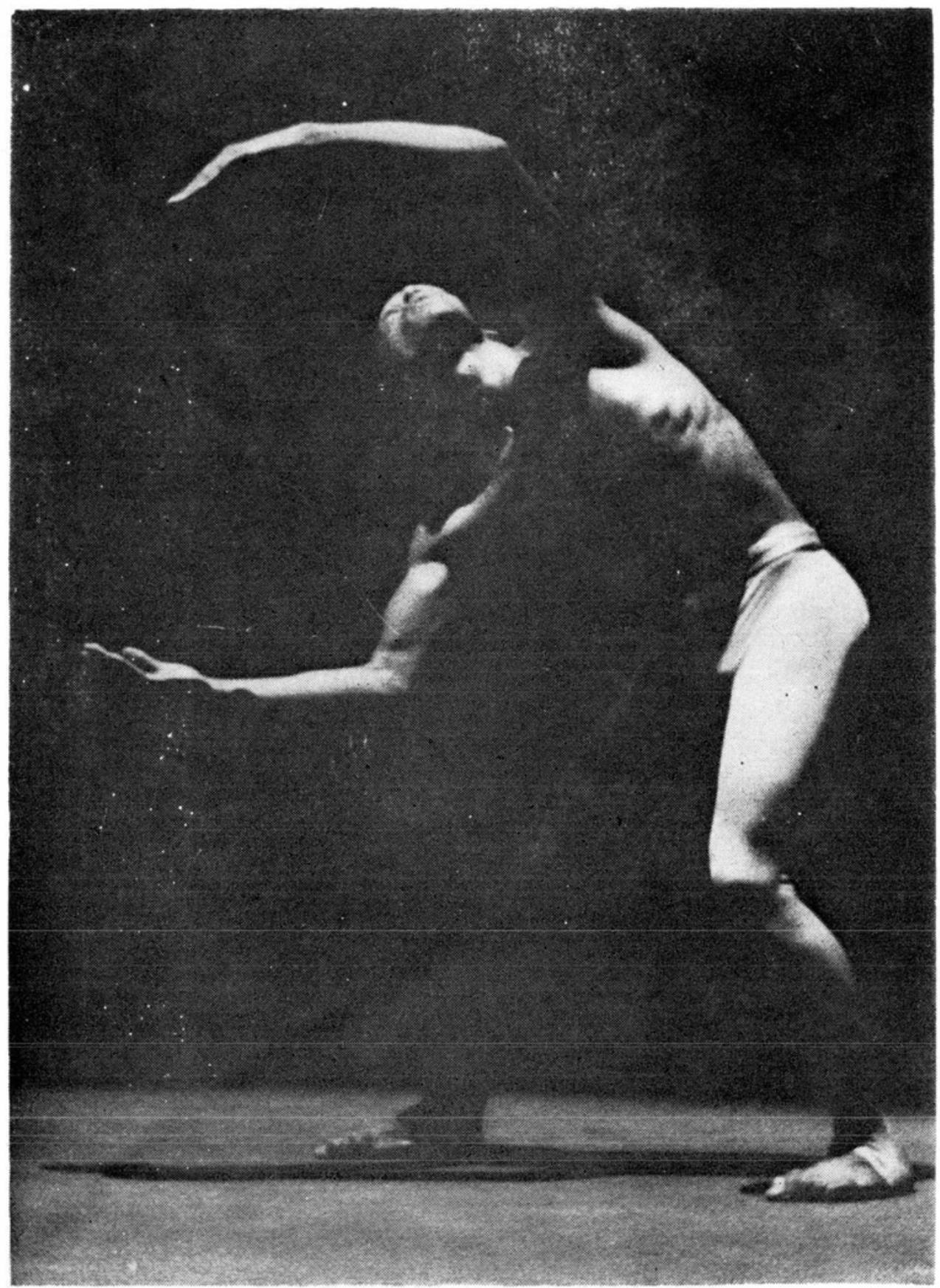

Figura 4. Jesús Romero en Estudio Nüm. 6 (Primer trazo sobre un Toto de Creta), de Guillermina Bravo. 1979. Foto: Renzo Góstoli. 


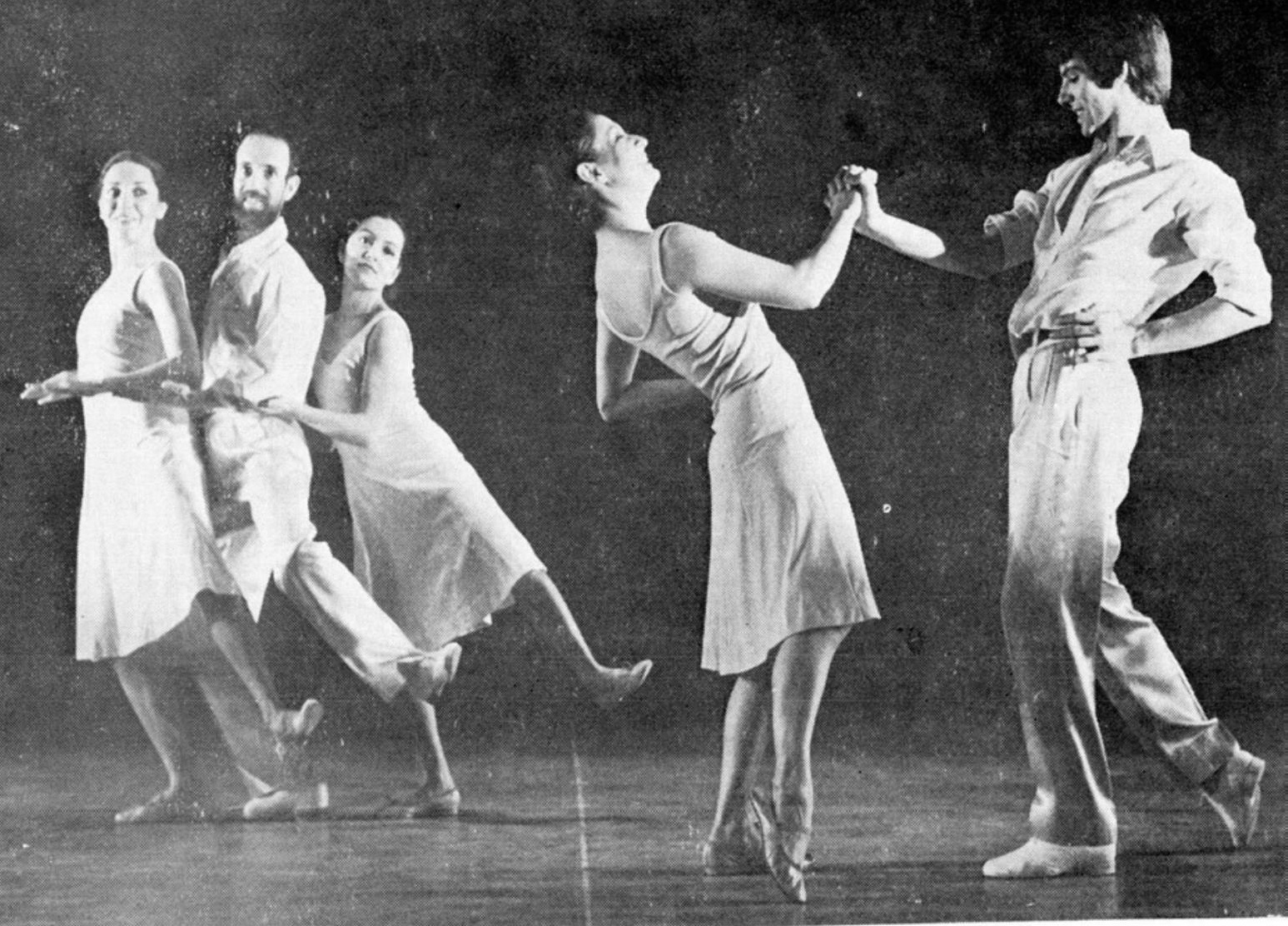

Figua 5. Forion Ensamble en La vieja historia de la Cenicienta, de Rosa Olivera. 1979. Foto: Antonio Berlanga. 


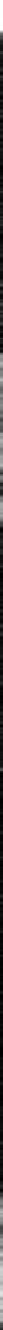

Figura 6. Ballet Nacional de México en La vida es sueño, de Guillemina Bravo, Jaime Blanc y Federico Castro, 1981. Foto: Rogelio Cuéllar. 
las costumbres dancísticas de los indígenas. En su afán de erradicar las prácticas paganas, los misioneros españoles "disfrazaron" algunas de las danzas originales y las orientaron hacia la adoración y los conocimientos del dios y de los santos cristianos. También utilizaron las danzas para enseñar el idioma y el ritual católico de los españoles. Pero el proceso contrario también ocurrió Los trabajos didácticos de los conquistadores no fueron suficientes para evitar que algunas de las prácticas dancísticas originales sobrevivieran callada, subrepticiamente y de esta manera los procedimientos de ciertas danzas (que en la actualidad se practican en distintos puntos del país) han resguardado su natural intensidad pagana. En efecto, en el México de hoy existe una enorme gama de actividades dancísticas que expresan desde las más auténticas y autóctonas rutinas hasta las más sofisticadas combinaciones de modalidades antiguas y contemporáneas. La danza autóctona, aun con los peligros de extinción y de tergiversación que hoy la acechan, es practicada por los grupos indígenas. La danza vernácula o folklórica es sumamente apreciada y frecuentada por los campesinos y la clase media urbana a lo largo y a lo ancho del país. Continuamente se llevan a cabo festivales y espectáculos de estos tipos de danza.

Por su parte, las danzas popular y social no sólo han surgido y han proliferado día con día desde el momento de la Conquista. País de fiestas, celebraciones y festividades, los habitantes de la República Mexicana, practican, difunden, inventan, expanden y recrean continuamente sus danzas populares, ya sea para presentarlas como espectáculos o bien como actividades normales dentro de cada comunidad, ciudad, pueblo, villorrio, etcétera.

Muchas de las inclinaciones rituales de nuestros ancestros prehispánicos tuvieron su prolongación en las danzas teatrales surgidas durante la dominación española $y$, posteriormente, a lo largo de nuestra vida independiente. En los escenarios mexicanos ha ocurrido siempre un intercambio vistoso y fructifero entre la danza popular y las distintas técnicas y pseudotécnicas de la danza teatral. En la actualidad es común descubrir muchísimas formas y variadísimas especies de expresiones dancísticas en los escenarios, pistas, tinglados y cabarets mexicanos: revista musical, sainete, zarzuela, género chico, comedia musical, show, etcétera Estas modalidades y expresiones han florecido a lo largo de cuatro siglos y algunas de ellas mantuvieron abiertas las expectativas de la población hasta las primeras visitas de los artistas del 
ballet, de los espectáculos de la ópera y la irrupción, en el siglo xx, de las danzas moderna y contemporánea.

México alcanza su independencia política en 1821. Sin embargo, las intervenciones ininterrumpidas que comienza a sufrir en suelo y en carne propios no únicamente son de indole militar y económica. Los avatares dancísticos, los ires y venires de las modalidades musicales y de los pasos y coreografías indican que las dificultades para que surja una danza propia, auténtica, natural, directa y espontánea en México, corren paralelas a las dificultades políticas y sociales a las que debe enfrentarse la joven nación. Asi, hay polkos que se rebelan, fiestas y canciones que casi se espetan bandos contrarios a la mitad de las batallas, y piezas musicales y dancísticas que delatan inclinaciones políticas e ideológicas. En fin, recuérdense, al comenzar la guerra de Independencia, los señalamientos en contra de la "balsa", "valse" y de la con. tradanza porque se trataba de ritmos e "invenciones ultraindecentes que la diabólica Francia nos introdujo". Durante casi todo el siglo xIx, en lo que a danza se refiere, entre los mexicanos no hay unidad pero sí lucha de contrarios. Todavía no existe el terreno adecuado para que surja una expresión dancística (y su paralela musical) propia y adecuada y todos sus productos se refieren a la lucha que aún tiene que librar la nación para especificar, de manera nacional, ambientes, situaciones, conductas, influjos y existencias. Todavía le ponen frases y palabras a los más cercanos parientes musicales de fuera para que surjan el canto y la danza mexicanos. Y es éste el acervo que quedará registrado, incorporado al surgir la República restaurada y al instalarse el Porfiriato.

El "alfabeto" musical y popular de México ha de establecerse a partir de estas épocas. La pax porfiriana servirá, entre otras cosas, para mirar y admirar la prolífica creatividad popular en las canciones y en las danzas. La nueva clase media "asentará" las modalidades ya existentes e inventará otras sin menospreciar las primeras. Aunque en ocasiones resulte superficial y clasista, "la mexicanidad" dancística y musical de la época extrae ciertos rasgos del mexicano que son de él y de nadie más, y habrá de popularizar, ahora si para siempre, ciertos códigos y procedimientos que culminarán en el surgimiento del corrido y en la incorporación definitiva a la cultura de México de las danzas folklóricas y de las danzas populares urbanas.

Canto y danza acompañan a los revolucionarios a lo largo y a lo 
ancho del pais a partir de 1910. Van con ellos, participan de sus certezas e inconsciencias y proponen nuevas expresiones inspirando sucesivamente obras y usanzas según levantamientos, triunfos, asonadas, venganzas, esporádicos asentamientos gubernamentales y trágicos desenlaces. A partir de 1920 afloran auténticos productos nacionales que corroboran y reiteran la vigencia paralela de una clase social (la pequeña burguesia) en la representación de las "fuerzas vivas" a través del gobierno de Álvaro Obregón. Por estas fechas surgen el "jarabe nacional" (1919), Mi querido capitán (1920), el Salón México y los hermanos Dominguez (1921). Durante la siguiente década (1920-1930) surgen los Tata Nacho, los Guty Cárdenas, Adiós Mariquita linda (1925) y muere Álvaro Obregón en La Bombilla (1928), pero también es el momento histórico en que se inicia la radiodifusión, la música grabada, el pleno auge de la canción popular y se abre un nuevo mundo para el canto y la danza de México. ${ }^{8}$

El arte mexicano no podía seguir siendo el mismo. La efervescencia revolucionaria obliga a una nueva búsqueda de lo nacional pero con reglas diferentes. Si el Porfiriato intentó explicar nuestra identidad mediante la exaltación formal y superficial de la indígena, de lo prehispánico, porque el artista, el creador se limitaba a "adaptar" el contenido a formas expresa y anteriormente importadas e impuestas, el arte de la Revolución Mexicana de 1910 tendría que ir hacia las raíces culturales y "ver" lo indígena con nuevos ojos, con ojos ahora limpios gracias a una distinta comprensión de la sociedad y sus componentes.

Los artistas de la época saben que tienen que ir con tiento, que deben ofrecer su nuevo producto artístico tras la militancia, la observación, la investigación. Deben ir hacia las instancias más explotadas y culturalmente olvidadas del pueblo: el campesinado, sector en el que de lleno se hallan los pueblos indígenas.. De esta manera, la danza co. mienza a "desenterrar" su historia y su geografía de la misma manera que lo hacen la pintura y la música. A principios de la década de los treinta no se sabe si la danza de la Revolución tendrá que acogerse a la arqueología (reconstrucción), a la historia (interpretación) o al reconocimiento de la tradición (reorganización). Los antecedentes más notables y respetables de la danza que hoy denominamos moderna o

8 Sobre el surgimiento y asentamiento de la danza popular urbana de la baja clase media mexicana, véase Alberto Dallal, El "dancing" mexicano, Ed. Oasis, México, 1982. 
contemporánea se hallan en las brigadas de maestros rurales que recorrieron el país incitando a las comunidades a incorporarse a la civilización, la tecnología, la industria. Ellos son los que comenzaron a retomar las auténticas raíces indígenas, los que registraron por primera vez sus modalidades y los que les indicaron a propios y a extraños los enormes valores entrañados, incrustados en la danza del pueblo mexicano. Durante estas incursiones de enseñanza e investigación murieron muchos profesores y maestros ya que el país todavía se hallaba agitado por huestes radicales que deseaban la implantación del orden anterior o bien propugnaban por llevar los proyectos de la Revolución Mexicana de 1910 hasta sus últimas y más radicales consecuencias.

Los primeros visos del arte dancístico mexicano de los años treinta son nacionalistas y revolucionarios. Los personajes de la danza popular de la época son, como en los murales de Diego Rivera, anónimos pero identificables: una combinación de tipos y prototipos; $y$, como ocurre en los murales de Diego Rivera, son personajes que apuntan hacia una identidad general no obstante la exaltación y esquematización y por ende, la limitación de sus rasgos.

Los murales de Diego Rivera en la Secretaria de Educación Pública ya están mirando al pueblo, al pueblo pueblo, y están dando al habitante común y corriente de México un arte que lo acerca más a su verdad, a reconocer una identidad no sólo cultural (que puede ser muy compleja, que puede ser muy subjetiva), sino asimismo una identidad social, o sea una visión real de la realidad. Es sintomático que en la Secretaría de Educación Pública, en un edificio que se halla enclavado en el centro de la Ciudad de México, no solamente se pinten los grandes murales, sino que en su patio se lleve a cabo la primera presentación masiva de una danza, que podríamos llamar folklórica revolucionaria, en el sentido de que no nada más busca la reproducción de lo regional, sino que trata, por medio de contenido y forma, de dar una nueva idea masiva de la danza. Precisamente en este edificio, en los años veintes, se organiza por primera vez una presentación de ese embrióñ de danza nacionalista que ya está en la atmósfera y que muchas personas harán surgir la siguiente década.

Al fundarse la Escuela de Danza en 1932 indudablemente se buscaba imprimir este sello de "expresión nacional" que ya cubría a la mayoría de las manifestaciones artísticas. La acción oficial en el plano del arte, la "batalla de la cultura", no podía prescindir del establecimiento de 
las bases para una danza teatral, "artística" realmente mexicana y profesional. Esta Escuela de Danza hace concretos estos rasgos y no por casualidad sus primeros directores son Carlos Mérida y Carlos Orozco Romero, pintores imbuidos ya de la tendencia moderna, revolucionaria y nacionalista del arte de la época. Carlos Mérida, guatemalteco, había trabajado durante ocho años con Rivera. Después había viajado a Europa, en donde había observado las importantes innovaciones teatrales y dancísticas de la época. La Escuela de Danza formará parte, como dependencia, del Departamento de Bellas Artes de la Secretaría de Educación y surgirá como una propuesta estética para el joven y el niño mexicanos. Proporcionará conocimientos y adiestramientos básicos para crear una danza netamente mexicana. De esta manera, en sus programas de enseñanza se entremezclan las mismas inquietudes que perturbaban las reflexiones de los teóricos y de los creadores mexicanos de la época. Entre las primeras "materias" se incluían el ballet clásico, los bailes mexicanos, los bailes populares extranjeros, el baile teatral, la escenografía, la plástica escénica y la música popular. El entonces jefe dell Departamento de Bellas Artes, José Gorostiza, podía entender que los primeros programas sólo ofrecían elementos básicos que prepararan a los alumnos para un nuevo tipo de expresión dancística que, sin negar la presencia de lo autóctono y de lo regional, impusiera normas clásicas, universales, que abastecieran técnicamente a las danzas mexicanas de conductos para su posible trascendencia.

En la Escuela de Danza participan como profesores Nelly y Gloria Campobello, Hipólito Zybine, Rafael Diez, Evelyn Eastin, Agustín Lazo, Francisco Ramírez, Ángela Tercero, Consuelo Cuevas y Jesús Dưón. En 1934 se lleva a cabo la primera presentación de los alumnos en un Festival de Danzas Mexicanas que tiene lugar en el Teatro Hidalgo. El director Carlos Mérida, hace constar que en 1932 la escuela ya había presentado "en un sencillo acto público algunos ejercicios coreográficos de índole netamente pedagógica"; aún así, no afirma contundentemente que se trate de una presentación profesional sino de "las primeras experiencias importantes que se han hecho para dar incremento a la coreografía mexicana, basadas en ritmos y en movimientos de las danzas rituales que se estudian en la clase de Ritmos Mexicanos". "y

El programa incluía Cinco pasos de danza, Danza de los concheros, 9 Texto del programa. 
Bailes istmeños, la Danza de los malinches y La virgen y las fieras. Como puede apreciarse, se deseaba dar a conocer manifestaciones dancísticas indígenas y "convertir danza en ballet" respetando "todo el espíritu de la danza mexicana". Todavía no se otorgan créditos completos; sólo se menciona una "dirección coreográfica de Gloria Campobello" ya que se trata fundamentalmente de una especie de interpretación libre de la coreografía original.

Ese mismo año de 1934 por primera vez visita México una bailarina norteamericana llamada Waldeen, quien acompaña al coreógrafo y bailarín japonés Michio Ito. Según la usanza de la época, la pareja incluía una combinación de números de danzas del mundo "recreadas" por medio de una técnica moderna. Nacida en Dallas, Texas, en 1913, Waldeen había estudiado en Los Ángeles, en la escuela de ballet de Kosloff. También había estudiado con Benjamin Zemach y adquirido gran experiencia con Michio Ito, con quien ya había viajado a Japón. Waldeen se presentó en diversos recitales de danza en los Estados Unidos y Canadá e impartió clases en Nueva York. Waldeen regresará a México en 1939, ahora para presentar una temporada en el Palacio de Bellas Artes en compañia del bailarín Winifred Widener. La Secretaría de Educación Pública la invita entonces a formar una compañía que desarrolle en México la tendencia moderna que ella domina. Acepta y comienza a buscar los posibles integrantes del grupo. Según Waldeen, en aquel momento sólo "había dos escuelas de ballet español y el inicio de hacer algo con la danza regional por iniciativa de Carlos Mérida, que trabajaba con las hermanas Campobello".10 La verdad es que existían otras escuelas, una de las cuales ya había recibido como alumnas a muchachas que no encontraron con las hermanas Campobello métodos de preparación adecuados y satisfactorios. Una de estas escuelas estaba dirigida por Estrella Morales. Durante su visita de proselitismo, Waldeen descubre a Guillermina Bravo y otras bailarinas que habrian de incorporarse a la compañía que estaba formando a petición de los círculos oficiales. Entre otras, las discípulas de Estrella Morales eran, aparte de Guillermina Bravo, Amalia Hernández, Josefina Lavalle y Lourdes Campos. EI estudio se hallaba ubicado en la calle de Tlaxcala, en la Ciudad de México.11

10 Waldeen, "Conversación sobre la danza en México" con Patricia Cardona, El Dia, 17 de julio de 1976, p. 21.

11 Guillermina Bravo a Alberto Dallal, entrevista, 1974, inédita. 
Waldeen percibe la necesidad de introducir en México la técnica de la danza moderna, ya para entonces desarrollada en los Estados Unidos y algunas partes de Europa. Asimismo, se ve atraída por las manifestaciones culturales del país. Para ella, en México y sus habitantes existían los elementos indispensables para alentar y desarrollar un tipo de danza "humanista". Como habría de explicar años más tarde, consideraba que la danza moderna "es una flama viviente, una llamarada que provoca al espectador, que estimula sus emociones y requiere su participación". ${ }^{12}$

Al organizar uno de los primeros grupos de danza moderna en México, Waldeen logra captar ese enorme caudal expresivo que durante siglos se había mantenido vigente en la danza y el arte mexicanos. Para ella la historia, la manera de ser de un pueblo, su idiosincrasia alimentarán directamente a la danza. Como muchos otros creadores, Waldeen considerará a la técnica sólo como un vehículo para alcanzar la expresión:

...Si un bailarín se abandona a sólo bailar conseguirá que florezca todo lo que ha aprendido, todo lo estudiado de técnicas diferentes, pero no hará surgir su auténtica concepción creativa. Es algo misterioso. El bailarín bailando, improvisando el movimiento por el movimiento, repite todo lo estudiado y nada más, o si está bien motivado, encauza ese movimiento, de algún modo, hacia su propia idea creativa. Generalmente el coreógrafo se satisface con el puro movimiento. Pero para mí eso no es coreografía: eso es autoindulgencia del bailarín. El movimiento en la danza es, en cierta forma, una vida simbólica. O más aún: es La Vida Simbólica. De tal modo que el creador de danza debe recurrir a su conciencia simbólica para que las percepciones de lo externo se transmuten en una realidad interior. $\mathrm{O}$ a la inversa: transmutar la cognición psíquica oculta en expresiones físicas capaces de revelar ríos de fantasía, ideas o imágenes transformadas en danza. Esto es para mí la alquimia de la danza. Esta alquimia, esta transmutación del fuego interior no se puede lograr sin técnica, por supuesto. La técnica es un instrumento; pero la invención del lenguaje, de la imagen, es otro. Y la técnica no muestra ese fuego íntimo. Esto es lo que no veo en la danza en México: la transmutación..$^{13}$

12 Raquel Tibol, "La filosofía de la danza moderna según Waldeen...", Excélsior, 27 de enero de 1975.

13 Waldeen, "La danza es una energía social", entrevista por Carlos Montemayor, Casa del Tiempo, vol I, núm junio de $1981_{\text {" }}$ 
El grupo que Waldeen organiza inicia su historia artística en noviembre de 1940 con una memorable presentación en el Palacio de Bellas Artes. Aparte de obtener un éxito sin precedente en la historia de la danza en México, especifica y concretiza las aspiraciones de crear un ballet auténticamente mexicano. Para ello cuenta con 1) una técnica nueva, adaptable al proyecto estético de la Revolución Mexicana; 2) un grupo de entusiastas y talentosos bailarines, principalmente mujeres; 3) el apoyo decidido de las autoridades oficiales de la cultura mexicana; 4) los brillantes y heroicos antecedentes de los maestros rurales y de las brigadas de intelectuales y artistas, y 5) la atención de creadores profesionales de las distintas y variadas disciplinas artísticas. Tanto los críticos como la prensa en general se dan cuenta de que esta presentación aprovechaba la existencia de una importante manifestación artística de alcances mundiales. Posteriormente, el Ballet de Waldeen tendrá la oportunidad de comprobar las certezas estéticas de sus esfuerzos porque con pleno éxito realiza una gira por los Estados Unidos y presenta su espectáculo en más de una docena de centros universitarios de ese país. Era el primer grupo mexicano de danza moderna que recreaba las raíces autóctonas y las expresaba mediante la técnica nueva. El grupo de danza asumía ya la preparación de nuevos cuadros y aprovechaba aquellos bailarines que habían respondido desde el principio a los requerimientos de Waldeen.

También en 1940 realiza su primera presentación "La Paloma Azul". Este año ofrece dos temporadas en el Palacio de Bellas Artes bajo la dirección de su fundadora, Anna Sokolow.

"La Paloma Azul" representa otra de las corrientes fundamentales del movimiento de danza moderna mexicana Anna Sokolow había actuado por primera vez en México en 1939, durante una visita que realizó al país con un grupo de bailarines norteamericanos. El grupo actuó en el Palacio de las Bellas Ártes bajo los auspicios del enton. ces Departamento de Bellas Artes, ofreciendo veinticuatro conciertos que fueron bien acogidos por la crítica, el público y el núcleo de artistas que por aquella época incursionaba, con sus propios medios, en la danza moderna.

Anna Sokolow nació en Hartford, Connecticut, el 22 de febrero de 1913. Se inició en la danza a la edad de 12 años, realizando todos sus estudios coreográficos en la ciudad de Nueva York. Fue discípula de Martha Graham y miembro de la compañía de la gran artista durante 
nueve años. Asimismo, realizó estudios de las distintas ramas del arte teatral. Al llegar a México en 1939 ya había actuado en conciertos, tanto en solos como en cuerpos de ballet, desde 1933. Se había presentado ya en todas las grandes ciudades de los Estados Unidos. También había actuado para ciertos públicos europeos. En 1937 se había incorporado, mediante una beca, al medio dancístico universitario de los Estados Unidos.

Una de las obras que Anna Sokolow preparó para las presentaciones de "La Paloma Azul" es la Sinfonia de Antigona. Ella misma desempeñaba el papel principal y la acompañaban Josefina Luna y Delia Ruiz, como los hermanos de Antígona, y un coro compuesto por el cuerpo de danza de "La Paloma Azul" que en aquella época estaba integrado por algunas muchachas que con el tiempo llegarian a destacar en la danza mexicana: Raquel, Carmen e Isabel Gutiérrez, Ana Mérida, Rosa Reyna, Martha Bracho, Estela Garfias, El decorado y el vestuario de la Sinfonia de Antígona fueron de Carlos Obregón Santacilia y la música fue compuesta por Carlos Chávez.

El lapso 1939-1940 resulta un periodo clave para la danza mexicana, no sólo porque estalla abiertamente la segunda Guerra Mundial y parte considerable de la actividad artística concentra sus objetivos en el continente americano, sino también porque se hallaban maduras las condiciones para el surgimiento de una danza moderna auténticamente mexicana, una danza que incorporara los elementos técnicos que en los Estados Unidos y en Alemania habían desarrollado y divulgado Ruth St. Denis, Martha Graham, Doris Humphrey y Mary Wigman.

Al grupo de "La Paloma Azul" se incorporan algunos creadores notables como Blas Galindo, Rodolfo Halffter, Manuel Rodríguez Lozano, Carlos Obregón Santacilia y otros. La consigna del grupo se refiere a una frase de uno de los grandes poetas clásicos españoles: "Las artes hice mágicas volando." En la portada del programa de la temporada de ese otoño de 1940, puede apreciarse un hermoso dibujo de Ramón Gaya alusivo a las musas de la danza, vestidas de una maneía muy especial, pues el atuendo combina los motivos balletísticos con un traje que evoca las luces de los toreros. Precisamente en este programa se presentó la obra La madrugada del panadero, coreografía de Anna Sokolow, decorado y vestuario de Manuel Rodríguez Lozano y música de Rodolfo Halffter. Las escenas burlescas de esta obra fueron trazadas por José Bergamín. La acción se lleva a cabo en cualquier pueblo de 
Andalucía. La escenografía evocaba precisamente la casa del panadero y la acción es la siguiente:

Anochece. La panadera sola, sentada a la puerta ante una mesita con panes. El horno encendido, que se irá apagando poco a poco hasta quedar enteramente oscuro con la noche.

Entrada sucesiva de diversos galanes, hasta cuatro, que se acercan a la panadera, a quien galantean y compran un pan. Cada uno de ellos, antes de salir, parte el pan, que contiene una carta; la leen, dando diversas muestras de regocijo, y salen.

Se hace noche. La panadera entra y cierra la puerta. Por la calle salen el farolero y la luna. El farolero enciende un gran farol esquinado. La luna huye. La panadera, mientras, ha encendido la lámpara. Llega por la calle un quinto galán retrasado. Llama a la puerta. La panadera abre. Sorpresa. Llega por la calle el panadero. Llama a la puerta inquieto. La panadera esconde al galán en un saco de harina y abre. E1 panadero busca por todos lados. Al fin se tranquiliza y se acuesta a dormir. También la panadera. Sale por la calle otro galán. Llama a la puerta. La panadera se levanta y con gran sigilo abre. Entra el primer galán. Se repite el juego con otro y otro, hasta cuatro. A cada uno de ellos la panadera lo va escondiendo en un costal de harina de modo que coincide el esconderlo con la llamada a la puerta del siguiente. Cuando están todos escondidos la panadera vuelve a acostarse.

Noche completa; de los costales en donde están los escondidos asoman, sucesivamente, de modo guiñolesco, las cabezas enharinadas de los galanes, y poco a poco, parte del cuerpo, todo emblanquecido. Se asustan mutuamente en un juego rítmico de fantasmas.

El panadero se rebulle en el lecho, inquieto. Los enharinados logran saltar de sus escondites. Al ruido, el panadero se despierta. Se tira de la cama. Los percibe. Se restrega los ojos, creyendo ver visiones. Los enharinados galanes se quedan inmóviles y cruzados de brazos como don Tancredo. El panadero adormilado, con ademanes inequívocos de toro fierón, se les acerca, les huele. Los galanes no se inmutan.

Poco a poco va clareando. La panadera finge que se despierta y al ver la escena se levanta y con una pala de horno persigue a los galanes, sacudiéndoles una verdadera paliza. El panadero la sigue estupefacto. Los tancredos, perdiendo su blancura, van reuniéndose, como cabestros, envolviendo al panadero y metiéndose todos por el horno, como por un toril, dejando al panadero afuera; éste, furioso y medio estorbado, medio ayudado por la panadera, prende fuego al horno.

Van llegando por la calle diversas gentes que vienen a comprar el pan. En vez del pan ven salir del horno a los galanes chamuscados. Sorpresa y regocijo general. Se ha apagado el lucero y entra por la 
ventana, glorioso, rubicundo, sonriente, el más dorado sol. Gran baile final con todos. ${ }^{14}$

También en 1940 se estrena la obra Don Lindo de Almeria. La coreografía es de Anna Sokolow, la música de Rodolfo Halffter, el argumento de José Bergamín y la escenografía y vestuario de Antonio Ruiz.

La danza moderna comenzaba a echar raíces en tierra fértil. Aparte de las cualidades propias de esta modalidad (a las que se adaptó perfectamente la naturaleza y la temática propias de la cultura mexicana), debe señalarse la existencia de cuadros dispuestos y aun expectantes que se integrarían a estas nuevas tareas creativas. También debe considerarse que el inicio de la danza moderna en México marca simultáneamente el principio de un movimiento, definiéndose éste como la acción conjunta y dinámica de un grupo considerable de creadores e intérpretes, de organizadores e intelectuales que dentro de una misma línea, estilo o género logran proponer al público, al pueblo un conjunto de obras atractivas y trascendentes. A veces se ha querido explicar el fenómeno del movimiento mexicano de danza moderna (que iniciara este numeroso grupo de bailarinas y artistas) mediante el argumento de que un movimiento semejante hubiera sido imposible de lograr por medio de la danza clásica, en aquel entonces limitada o desarrollada deficientemente en México. En realidad, fue su contun. dente adaptabilidad como género (sobre todo en el grado de desarrollo que históricamente había alcanzado ya por esas fechas) a los temas, a la manera de ser e incluso a la voluntad cultural de México. Con todo, el factor primordial se refiere a la confluencia notable de circunstancias y personas asi como a la necesidad expresa de satisfacer demandas artísticas y sociales específicas.

En 1943 las hermanas Campobello fundan el Ballet de la Ciudad de México. Nelly funge como directora general y Gloria como primera bailarina. En el mes de junio ofrecen sus primeras presentaciones como compañía profesional interpretando las siguientes obras: Fuensanta, Alameda 1900, Las silfides y La siesta de un fauno. Evidentemente dos hechos resultan antecedentes directos de la creación de una compañía de danza clásica con las características del Ballet de la Ciudad de México: en primer término, la visita que en 1942 y bajo los auspicios de

14 Notas al programa. 
la Dirección de Educación y Estética (administrada por Benito Coquet) de la Secretaría de Educación Pública realiza el Ballet Theatre, la gran compañía norteamericana que contaba con figuras tan excepcionales como Alicia Markova, Anton Dolin, Irina Varanova, Jerome Robbins, Lucía Chase y muchos otros; en segundo término, el deseo de incorporar el tema mexicano a la técnica clásica, ambición ya evidente en la antigua Escuela de Danza, por estas fechas designada ya como "Nacional"."15 El Ballet de la Ciudad de México quedará disuelto en 1947 aunque seguirán funcionando por mucho tiempo las instalaciones de la Escuela Nacional de Danza. En sucesivas temporadas, durante los años siguientes, esta compañía de danza clásica estrena obras como: Obertura republicana, Presencia, Circo Orrin, El sombrero de tres picos, Vespertina, Ixtepec, Glase de ballet y Pausa.

Capítulo importantísimo en el desarrollo de la danza mexicana representa la separación que por esta época ocurre entre las técnicas y los temas del quehacer dancístico. En efecto, cuando se hablaba de "lo nacional" o de "lo mexicano" los artistas e intelectuales no siempre se referían a lo mismo. Algunos tenían buen cuidado de no caer en el concepto fácil, simplista y superficial que acabó por caracterizar a la producción artística del Porfirismo, concepto más bien autoritario y paternalista que procedió a la sofisticación y el amaneramiento de los motivos y temas indígenas. Era éste uno de los grandes problemas de la danza teatral mexicana de la época, clásica o moderna: sólo "apoderarse", "robar" elementos periféricos, exteriores de la tradición nacional para producir un arte reiterativo, endeble y epidérmico.

El presidente Lázaro Cárdenas y los artistas, intelectuales y creadores conscientes de la época se dan cuenta de la riqueza artística y cultural inmersa en la cotidianeidad indigena, en sus formas de vida y de organización. Asimismo, se percatan de la necesidad de salvaguar los valores autóctonos a la manera en que los primeros maestros rurales y brigadistas culturales lo hicieron: proponiéndole al indígena medios, procedimientos y recursos materiales y culturales que no afectaran sino apoyaran y desarrollaran sus ya existentes dotes y características.

Debían quedar asimilados al pais nuevos métodos, nuevos sistemas, nuevas técnicas dancísticas. Buen cuidado se requería para no tergiver-

15 Recuérdese asimismo que en sus visitas a México Anna Pávlova baila en puntas El jarabe tapatio Véase Alberto Dallal, "La danza moderna en México", en La danza contra la muerte, Universidad Nacional Autónoma de México, 2a ed, 1983 
sar los elementos originales (en este caso indígenas) y sí "procesarlos" en su plena autenticidad. Otro de los enormes factores en la iniciación de un movimiento como el de la Danza Moderna Mexicana se refiere a la intervención de un proceso inverso: los nuevos creadores se "alimentaron" de la creatividad indigena, de sus símbolos, de sus actitudes y productos. De otra manera no se entendería el auge sorprendente (que irrumpe y pexdura por un lapso de quince años, 1940-1955) de un movimiento artístico que prácticamente carecía de sustento técnico, circunstancia que se hará evidente en sus postrimerias.

Como acción de búsqueda, la danza moderna mexicana tenía como base otras instancias del hacer artístico (que respetaban al máximo la creatividad indígena) y un programa que en aquel momento resultaba claro:

La fórmula de "incorporar al indio a la civilización", tiene todavía restos de los viejos sistemas que trataban de ocultar la desigualdad de hecho, porque esa incorporación se ha entendido generalmente como propósito de desindianizar y de extranjerizar, es decir, de acabar con la cultura primitiva; desarraigar los dialectos regionales, las tradiciones, las costumbres, los vestidos, el arte autóctono y hasta los sentimientos profundos del hombre apegado a su tierra. Por otra parte, ya nadie pretende una resurrección de los sistemas indígenas precortesianos o el estancamiento incompatible con las corrientes de la vida actual. Lo que se debe sostener es la incorporación de la cultura universal al indio, es decir, el desarrollo pleno de todas las potencias y facultades naturales de la raza, el mejoramiento de sus condiciones de vida agregando a sus recursos de subsistencia y de trabajo todos los implementos de la técnica, de la ciencia y del arte universales, pero siempre sobre la base de la personalidad racial y el respeto de su conciencia y de su entidad. El programa de emancipación del indio es en esencia el de la emancipación del proletariado de cualquier país, pero sin olvidar las condiciones especiales de su clima, de sus antecedentes y de sus necesidades reales y palpitantes ${ }^{16}$

Para 1945 el grupo de danza de Waldeen había ya viajado por Estados Unidos y tenía un vasto repertorio de coreografías de la artista norteamericana. La fundación del Ballet de Waldeen no solamente reconocía los beneficios de la presencia de la bailarina y coreógrafa nor-

16 Lázaro Cárdenas en el Primer Cong1eso Indígena Interamericano, Pátzcuaro, 14 de abril de 1940 , en Victoria Lerner, La educación socialista, tomo 17 de la Historia de la Revolución Mexicana, El Colegio de México, 1979, p. 141. 
teamericana en México durante los años anteriores; también informaba de la vigencia de una nueva modalidad o género de danza que permit́a la expresión directa de los elementos y temas auténticamente nacionales.

En noviembre-diciembre de 1945 se organiza una breve temporada en el Palacio de Bellas Artes con un programa constituido exclusivamente con obras de Waldeen: Elena la traicionera, Suite de danzas, Cinco danzas en ritmo búlgaro, Danza de los desheredados (del ballet La Coronela), Alegretto de la Quinta sinfonía y el ballet-corrido en tres partes Elena la traicionera. En estas presentaciones ya puede apreciarse la afluencia de nuevos cuerpos y rostros, intérpretes y actuaciones que dan pábulo al nacimiento de una danza mexicana entusiasta y vigorosa. Además de Waldeen intervienen: Guillermina Bravo, Lourdes Campos, Edmee de Córdoba, Ana Mérida, Gloria Mestre, Evelia Beristáin, Ricardo Silva, José Silva, Juan Ruiz, Alberto "Grishka" Holguín y otros artistas que alternan sus papeles secundarios con los cantantes y el coro. En ese momento ya se cuenta con las colaboraciones de los escenógrafos Carlos Mérida, Julio Prieto, Olga Costa, Gabriel Fernández Ledesma, Julio de Diego, Dasha, Manuel Meza; de los compositores Carlos Chávez, Rodolfo Halffter, Blas Galindo, Silvestre Revueltas. Como director de escena colabora Seki Sano, como pianista Miguel García Mora y como actores Carmen Hermosillo y Ramón Gay. La temporada estuvo patrocinada por la Secretaría de Educación Pública, entidad que ofrecía al público un tipo de danza que durante esos últimos veinticinco años venía siendo

una de las artes de mayor significación en nuestra vida contemporánea. A través del mundo, la historia ha mostrado que la danza ha sido siempre la expresión de un pueblo y una época y no nada más una expresión artística aislada, individual. Es por esto que podemos ver a la danza moderna como nuestra propia danza: es la cristalización creada de nuestras experiencias vitales en todos los planos: mental, emocional, espiritual o social ...17

Wadeen decide irse del país y en 1946 Ana Mérida y Guillermina Bravo fundan el Ballet Waldeen, incorporando a este compacto y bien organizado grupo a todos los bailarines que con la más o menos reciente salida de la maestra y la ausencia de Anna Sokolow habían

17 Texto del programa. 
quedado a la expectativa de nuevos trabajos. E1 Ballet Waldeen constituyó un acto de reconocimiento a las bases coreográficas que había echado la artista norteamericana pero al mismo tiempo era la forma en que las jóvenes bailarinas mexicanas hacían evidentes sus presencias en el arte del país. A una memorable presentación que realizan en una sala de cine acuden las autoridades culturales (representadas por Carlos Chávez, a la sazón jefe del Departamento de Bellas Artes); también acude lo mejor de la crítica del país y obtienen las organizadoras un resonado éxito.

En 1947 se organiza la Academia de la Danza Mexicana. La institución tuvo su primer domicilio en la Iglesia de San Diego, donde, como reza el letrero, "estuvo durante la Colonia el quemadero de la Inquisición". Fundada por iniciativa y con el apoyo completo de Carlos Chávez, cuando el compositor convierte el Departamento de Bellas Axtes en el Instituto Nacional de Bellas Artes, la Academia de la Danza Mexicana constituyó una alternativa a la Escuela Nacional de Danza que para muchos no satisfacía las demandas y las necesidades de preparación dancística de la época. Las primeras directoras de la Academia de la Danza Mexicana fueron Guillermina Bravo y Ana Mérida, las destacadas artistas alrededor de las cuales se habian reunido todos los jóvenes bailarines y bailarinas que buscaban el perfeccionamiento de las reducidas enseñanzas técnicas que Waldeen y Anna Sokolow les habian dejado.

Poco se sabe de las razones por las que un año después de fundada la Academia Guillermina Bravo sale de su puesto de codirectora. No pacas personas supieron, sin embargo, que la salida de Bravo se refirió a murmuraciones emitidas en torno a su supuesta o no militancia en el Partido Comunista. La misma Guillermina Bravo resultó parca en torno al tema. Aún ahora deja entrever la posibilidad de que sobre su trabajo pesaran falsas acusaciones de sus compañeros sobre la cxistencia de una "célula comunista", naturalmente comandada por ella, en la academia. Con todo, Guillermina acepta, sí, que su salida le permitió fundar en 1948 el Ballet Nacional de México, la institución más antigua, estable y consistente en su género no sólo en el país sino en América Latina. Debe considerarse tan sólo que de esta compañía independiente surgieron los principales cuadros de la danza moderna y de la danza contemporánea de México; que hasta la fecha propone la línea dancística profesional más seria del pais; que en 
todas estas décadas ha constituido una especie de centro de práctica contemporánea de las artes escénicas. Asimismo, su estabilidad y madurez artística profesional sólo puede compararse a la vigencia de la línea clásica alcanzada por el ahora Ballet Nacional de Cuba, fundado por Alicia y Fernando Alonso en La Habana, en ese mismo año, con el nombre de Ballet Alicia Alonso.

Las primeras promociones de la Academia de la Danza Mexicana estuvieron integradas por bailarinas y bailarines que habian transitado ya por la técnica clásica, inquietos cuadros dancísticos que al decidir la asimilación de una modalidad distinta a la clásica, por lo menos hicieron valer los conocimientos de danza clásica que las hermanas Campobello les habían transmitido. En la lista de estas pioneras de un movimiento que resulta notable y original incluso a escala mundial destacan, además de los nombres de Guillermina Bravo y Ana Mérida, los de Amalia Hernández, Martha Bracho, Martha Castro, Rosa Reyna, Raquel Gutiérrez, Josefina Lavalle y Evelia Beristáin "Todas ellas convergieron hacia las actividades coreográficas con un mínimo de elementos teóricos y técnicos pero con un entusiasmo sólo comparable al de aquellos artistas que conformaron, estructuraron y realizaron lo que la historia de la pintura del mundo conoce ya como la escuela muralista mexicana y la música nacionalista mexicana. Asimismo, todas ellas fueron incor porando rutinas, secuencias, tratamientos a su propia línea creativa e interpretativa.

Para 1949, el por aquel entonces director de la Academia de la Danza Mexicana, Fernando Wagner, hacía hincapié en que en México trabajaban ya "cuatro o cinco coreógrafos de porvenir": Guillermo Keys (por ei Don Juan de Strauss), Amalia Hernández (por la Sinfonia india de Carlos Chávez). Ana Mérida (por La luna y el venado y Norte de Luis Sandi), Raquel Gutiérrez (por La madrugada del panadero de Rodolfo Halffter), Beatriz Flores Castro (por Danza fúnebre de Jiménez Mabarak) y Rosa Reyna y Martha Bravo (por la Suite de Scarlatti.).

Fernando Wagner hablaba ya de una situación en la que los principales escollos habían sido salvados. Hacía dos años que la Academia de la Danza Mexicana realizaba presentaciones profesionales y uno desde que había sido fundado y trabajaba a todo vapor en su propio local el Ballet Nacional de México. Quede aclarado que por aquel entonces la vida profesional de la danza requería del sacrificio de sus 
integrantes pues aun contando con el apoyo de las autoridades competentes las condiciones de trabajo en las instalaciones de la Iglesia de San Diego, no eran, ni mucho menos, las apropiadas para que los jóvenes bailarines y los nuevos coreógrafos recibieran sus clases y ensayaran sus obras. Para trabajar,

las pobres bailarinas llevan no sólo las clásicas zapatillas, sino además guantes de lana, porque el frío las hace bailar de manos. Sentada en la barra, apoyada en el espejo con gxave riesgo de romperlo, Rosa Reyna tirita con un estilo digno de la Karsabina. Por su parte, Martha Bracho se ha envueto en las cortinas de un viejo decorado y sólo se atreve a asomar la punta de su ya escasa nariz. Entre tanto, Raquel Gutiérrez logra adquirir calor a fuerza de hacer corajes, pues los bailarines no logran aprenderse sus papeles de La madrugada del panadero con la rapidez que ella hubiera querido. Raquel está desesperada. Es la autora de la nueva coreografía y se encuentra con que, a última hora, varios de sus bailarines han sido separados de la Academia. Disciplina, pero zqué solución le queda? 18

No obstante sus limitaciones, la Academia de la Danza Mexicana contaba con la persistente energía de sus profesores y alumnos, los cuales estaban conscientes de que

la danza moderna tiene un poder expresivo mucho más rico que la clásica. Carece del amaneramiento de ésta y tiene mucho mayores posibilidades plásticas. Pero no debe ser un pretexto para disfrazar la falta de técnica. Las buenas bailarinas de moderno deben dominar también la técnica clásica. ${ }^{19}$

Asimismo, estaban conscientes de que la danza moderna mexicana aglutinaba ya a un numeroso y cada vez más entusiasmado contingen. te de artistas mexicanos de todas las disciplinas y campos: escenógrafos, pintores, poetas, escritores, compositores, diseñadores, fotógrafos, etcétera. Esto venía ocurriendo desde que el trabajo conjunto de Guillermina Bravo y Ana Mérida habían permitido la incorporación de nuevos temas y realizaciones en los espectáculos de la compañía adscrita a la academia. En efecto, en una función ofrecida el 12 de marzo de 1947, el programa quedaba integrado por obras de muy

18 Wanderer, "Martha y Rosa María", México en la Cultura, Supl, de Novedades, núm 44, 4 de diciembre de 1949, p. 4.

19 Ibid. 
distinta indole. Se bailaba la Sonata número 7 (primer movimiento) en el que su coreógrafa, Guillermina Bravo, intentaba reflejar, tras la música de Prokofiev, "diversos aspectos de la vida moderna: el movimiento incesante de las maquinarias, su ritmo acelerado; la guerra, el dolor, la tragedia que surge en consecuencia; al fin el impulso decisivo para alcanzar más desenvolvimiento, verdadera libertad".,20 Por su parte, la coreografía de Ana Mérida, El paraiso de los negros apro. vechaba la capacidad rítmica, los movimientos, los gestos y actitudes de los bailables negros de los Estados Unidos, utilizando el jazz (de reconocidos antecedentes en la música francesa y española del siglo xvIII) "en rara combinación con la música que esclavos negros trajeron de Africa a los países del Golfo y del Caribe". La coreografía de Ana Mérida recreaba sensaciones e imágenes plásticas "alrededor de una de las más fuertes expresiones populares de baile de la época presente". ${ }^{21}$ El cuarteto opus 59 núm. 3 de Beethoven (segundo movimiento) le permitía a Guillermina Bravo diseñar una "danza de amor" siguiendo exclusivamente las líneas melódicas de una pieza "apasionada e intensamente romántica del compositor". El programa, presentado en el Palacio de Bellas Artes culminaba con la coreografía de Waldeen En la boda, inspirada y apoyada en los sones de Jalisco y en la que la coreógrafa norteamericana "jugaba" con personajes de la provincia mexicana: la novia, el novio, las madrinas, las invitadas y los invitados.

La fundación del Ballet Nacional de México en 1948 marca un hito en la historia de la danza en México. Guillermina Bravo, creadora de esta institución, se ha referido muchas veces a la trayectoria de la única compañía de danza moderna y contemporánea en el país que ha logrado resolver todos los escollos y dificultades y mantenerse viva y creativa durante más de treinta y cinco años. ${ }^{22} \mathrm{Si}$ Waldeen fue un modelo para Guillermina Bravo, un ejemplo a seguir desde 1940 hasta 1947, año en el que se crea la Academia de la Danza Mexicana, la coreógrafa mexicana se erigió a su vez en modelo de muchas de las figuras de la danza mexicana durante varias generaciones. Hasta la fecha, la Bravo constituye una especie de fuente energética quie

20 Texto en el programa de mano.

21 Ibid.

22 Véase al respecto Alberto Dallal, La danza moderna, México, Fondo de Cul. tura Económica, 1975 
ofrece, propone, negocia e incluso espeta e impone puntos de vista, proyectos, realizaciones, pero que mantiene vigentes las instancias profesionales de la danza contemporánea. El apoyo que Carlos Chávez le otorgó a partir de 1947, la artista lo ha logrado, por la vía del convencimiento o por la fuerza de su obra, de los sucesivos directores del Instituto Nacional de Bellas Artes y de los dirigentes de muchas de las instituciones culturales de México. El impulso que ha recibido la danza mexicana a partir de Guillermina Bravo trasciende las enseñanzas de la maestra, los auxilios de la compañera de trabajo y las batallas gremiales. Directa o indirectamente, aun en las épocas de decaimiento evidente de las actividades dancísticas mexicanas, Guillermina ha defendido los derechos y la libertad que la danza moderna, primero, y la danza contemporánea, después, se han ganado a pulso y dentro y fuera del país.

Desde 1940 Guillermina Bravo ha mantenido firmes sus convicciones y sus principios estéticos. Su trayectoria como creadora ha ido desarrollándose en línea recta; ha evolucionado pero nunca ha cedido a lo fácil ni vuelto los ojos en dirección del oportunismo estético. De esta manera, la trayectoria coreográfica y estética de Guillermina Bravo está compuesta de etapas claras y sucesivas, distintas en lo que a madurez y recursos propios se refiere, pero única y segura en cuanto a concepciones básicas. Por ejemplo, Guillermina reconoce aún ahora que la danza moderna y contemporánea es un producto que se enfrenta y en muchos aspectos técnicos y expresivos supera a la danza clásica. Su obra ilustra hasta hoy este principio fundamental.

Nacida en Chacaltianguis, Veracruz, el 13 de noviembre de 1920 Guillermina estudió en la Escuela Nacional de Danza (1936) y, como se ha visto, en 1940 se incorpora al grupo formado por Waldeen. ${ }^{23} \mathrm{De}$ su Ballet Nacional de México surgieron las principales figuras de la danza mexicana y recibieron de Guillermina Bravo esa actitud de observar e investigar que ella, a su vez, había asimilado de las primeras épocas del movimiento. Si antes de la creación de su grupo, Bravo ya había estudiado las danzas indígenas y populares en Oaxaca, la costa del Pacífico y el Istmo de Tehuantepec, una vez alejada de los avatares administrativos y burocráticos de los medios oficiales, emprende una tarea de creación y divulgación que la hace relacionarse con la pro-

23 Diccionario del ballet $y$ de la danza, Batcelona, Editorial Argos, s/f 
ducción cultural de los indígenas y a la vez llevar obras accesibles mediante una nueva técnica. De esta manera, Bravo logra el antiguo sueño de los profesores itinerantes, de los precursores de la danza moderna y de los mismos protagonistas de ella. Hasta la fecha,

su producción sigue un curso variable que va desde el realismo nacionalista hasta la geometría abstracta de los últimos tiempos... Cada crítico prefiere unos estilos sobre otros pero nadie niega la formidable contribución de Guillermina Bravo a la danza contemporánea. Nadie desconoce, tampoco, sus principales virtudes: la autenticidad y la independencia de criterio, la perseverancia y el poder creativo. ${ }^{24}$

La obra general de Guillermina Bravo requiere ya de estudios especializados, de registros funcionales y de una ubicación teórica de sus distintas etapas creativas, probadas todas ante el público. Sus conocimientos en torno a las artes de espectáculo la han convertido en una figura notable del arte actual en América Latina. La Bravo, Premio Nacional de Arte 1979, dejó de bailar en 1960 para dedicarse exclusivamente a la creación coreográfica. Debe señalarse, además, que la vitalidad de su acción creativa concuerda perfectamente con su idea actual, contemporánea, de lo que puede y debe ser una compañia profesional:

Para mí, Ballet Nacional es muchas cosas pero principalmente dos: por un lado, un grupo que intenta tener un repertorio $y$, por otra parte, un grupo que siempre se halla en una actitud autocrítica. Sobre esto último puedo asegurarte que nosotros mismos, junto contigo y con otras personas, somos nuestros mejores críticos Queremos tener siempre un repertorio probado que a la vez posea el mérito de ser aceptado por el público. Que sea impecable en sus aspectos técnicos, que tenga un esquema de lucha bien definido, que tenga un vestuario bien diseñado y que junto con los demás elementos pueda ir por el mundo y a través de sus presentaciones expresar que existe, y explicar cómo es, la danza contemporánea de México. Hay otro aspecto sobre el cual siempre estamos atentos. Sobre este aspecto siempre estamos retrocediendo: damos un paso atrás para echar la carrera. Ballet Nacional es un grupo experimental. Siempre está formado, sacando, preparando coreógrafos y perpetuamente está

24 Palabras del Secretario de Educación Pública, licenciado Fernando Solana, en el acto de entrega de los Premios Nacionales 1979. Recinto de la Secretaría de Educación Pública, 26 de noviembre de 1979. 
ofreciendo a México nuevos bailarines. Es el ballet más antiguo. Además, es el ballet en el que más jóvenes bailarines existen. ${ }^{25}$

A partir de 1947 y durante la década completa de los cincuenta, Guillermina Bravo estrena muchas obras importantes que llevan la tónica general del primer impulso de la danza moderna mexicana. Aunque ella las clasifica como obras nacionalistas, "obras realistas de temas sociales", existen enormes diferencias entre unas y otras. Si bien es cierto que el denominador común de todas ellas se vincula directamente con "el camino único y el más seguro" al que se refiere Raúl Flores Guerrero para la danza mexicana, el más certero "por razones de orden emotivo, tradicional, temático, dinámico y aun técnico para que México se signifique artísticamente en el campo coreográfico", ${ }^{26}$ sobrevienen algunos contrastes notables entre El zanate (música de Blas Galindo, diseños de Gabriel Fernández Ledesma) y Preludios y fugas (música de Bach, diseños de Guillermo Meza), ambas obras de 1947, o bien entre Fuerza motriz (música de Carlos Chávez y Prokofiev, diseños de Horacio Durán) y Recuerdo a Zapata (música de Carlos Jiménez Mabarak, diseños de Leopoldo Méndez). En el último par de obras los bailarines aparecen como un bloque-masa, en el primer caso, y como personaje-coro, en el segundo. Asimismo, existe una distancia considerable entre el simbolismo épico o semiépico de Alturas de Macchu Pichu (1952), La conquista del agua (1952) y Guernica (1952) y el ruralismo de La nube estéril (1953); así como entre el semisimbolismo de Rescoldos (1954, obra suspendida por las autoridades del Instituto Nacional de Bellas Artes), y el cosmopolitismo de Danzas sin turismo (1955), El demagago (1956) y una obra precursora, vislumbradora, que a no ser por la autenticidad de su coreoatura en lo que respecta a sentido y estructura, obtendría un fácil éxito en su actual reposición: Braceros (1957).

No obstante la efusiva inclinación por los temas sociales y nacionales experimentada por el público de aquella época (Ballet Nacional salía a bailar a pueblos, ejidos, escuelas, plazas de toros e incluso milpas), la coreógrafa mexicana y sus compañetos de oficio estaban cons-

25 Guillermina Bravo, "Creatividad coreográfica en el Ballet Nacional de México", entrevista por Alberto Dallal, Retrista Mexicana de Cultura, VII época, núm. 93,21 de octubre de 1979, p. 1.

26 Raúl Flores Guerrero, "La danza contemporánea", Artes de México, año III, núms. 8 y 9 , marzo-agosto de 1955 , p. 61. 
cientes de que frecuentaban un género nuevo, una modalidad contemporánea; poseían un concepto correcto y claro del tipo de danza que ofrecían:

Nosotros nunca copiábamos las danzas a pesar de que buscábamos las festividades. Estábamos al tanto de los calendarios indígenas e ibamos a ver las danzas. En muchos casos acudíamos para aprender a bailarlas. Nunca hicimos danzas copiadas, por lo menos Chepina Lavalle, yo y Carlos Gaona, que éramos los coreógrafos. Jamás copiábámos los pásos sino que íbamos al mito. $\mathrm{O}$ sea: lo que nos interesaba de la danza indígena no era la danza misma sino el por qué la bailan. Inconscientemente buscábamos la raíz del mito: por qué bailaban ellos. Y de ese mito nos hacíamos para hacer una danza inventada. Así surgió Recuerdo a Zapata y así fue como hice El pa. raiso de los ahogados junto con Jiménez Mabarak. Fue muy valiosa su aportación en ese sentido. Jiménez Mabarak fue el que más abundantemente cosechó de ese concepto. Por ejemplo, en El paraiso él manejó música de un cantante yaqui pero distorsionándola de una manera formidable, transformándola a la manera electrónica porque no había laboratorios ni aparatos, pero sí rudimentariamente en el laboratorio de Hellmer. Allí, en Bellas Artes, había una especie de laboratorio. Jiménez Mabarak la hizo distorsionándola con sonidos, con ruidos de agua de llaves, de cristales, de una serie de objetos. No quería dejar la música tal cual era. Ahora en todas estas danzas de las que te hablo no hay un solo paso copiado. En El zanate yo tomé el mito. Es un animal que se mete a las casas y roba, para hacer sus nidos, los carretes de hilo, los pedazos de pan, los trapos. Es un animal ladrón. Pues bien, para hacer la danza tomé ese mito. Eso era mucho más profundo que los pasos indígenas que se bailan en Oaxaca. Más que los pasos mestizos Nunça se me ocurrió poner un paso de La zandunga. Sí, creo que éste era un camino correcto para alcanzar la verdadera investigación. Investigar por qué el indio baila. Eso ya casi se ha perdido. Ahora ya no saben por qué bailan los indigenas. Ahora queda la cáscara. Nada más la cáscara, lo superficial. ${ }^{27}$

Al mismo tiempo que Guillermina Bravo inaugura su etapa "no realista con temas mágico-rituales", Miguel Covarrubias, como jefe del Departamento de Danza de Bellas Artes, abre las posibilidades de proporcionar una mayor enseñanza técnica, auspicia la creatividad de los bailarines mexicanos y llama a algunos maestros y artistas extranjeros para ofrecer muestras trascendentes y fehacientes de las virtudes de la danza moderna.

27 Guillermina Bravo a Alberto Dallal, Entrevista, 1974, Inédita. 
Pocas han sido las ocasiones en la historia de la cultura mexicana en las que el especialista de un campo de conocimiento pone su experiencia y entusiasmo al servicio exclusivo de una actividad artística, hasta lograr impulsarla de tal manera que su intervención marque el antes y el después de dicha actividad. Tal es el caso de Miguel Covarrubias (1904-1957). Sería difícil hablar de la "especialidad" de Covarrubias pero habrá que señalar que sus principales habilidades artísticas se centraron, al iniciar su carrera, en el diseño comercial, la caricatura, el dibujo, la pintura, la edición de libros. Conocido por sus textos e ilustraciones chuscas, Covarrubias decoró y realizó mapas estupendos en los que especificaba las hermosas tareas artesanales indígenas. Posteriormente publicó The Eagle, the Jaguar an the Serpent (1954) $\mathrm{e}$ Indian Art of Mexico and Central America (1957), obras editadas en español por la UNAM (1961).

Durante su gestión como funcionario de la danza en el Instituto Nacional de Bellas Artes impulsó a tal grado las actividades de este arte que en su época culmina el movimiento mexicano de danza moderna, en el cual él interviene también como escenógrafo y diseñador de vestuario. Durante un lapso determinante, Covarrubias se interesó por la difusión y la enseñanza de la danza moderna, por la producción de nuevas obras, por brindar apoyo técnico y presupuestal a coreógrafos, compositores, escenógrafos y bailarines; así, durante diez años, en México destacó una danza moderna de tendencias nacionaleş (y en ocasiones nacionalistas) claramente expuestas. Asimismo, durante la administración de Covarrubias visitaron el pais, en varias ocasiones, compañías extranjeras como las de José Limón y profesores connotadọs como David Wood y Xavier Francis. Hábil y fantasioso creador de escenografías y vestuarios, a Miguel Covarrubias se deben los diseños de; entre otras obras, Los cuatro soles (coreografía de José Limón, 1951), Tonantzintla (coreografía de José Limón, 1951), Tózcatl (coreografía de Xavier Francis, 1952), El invisible (coreografía de Elena Noriega, 1952).

Miguel Covarrubias brindó amplio apoyo a los grupos y artistas que por xazones de organización y/o de actitud estética formaron entidades independientes, separadas de las esferas institucionales oficiales. Buen observador de la necesidad de ciertos creadores de trabajar en un ámbito libre de interferencias filosóficas y burocráticas, Covarrubias siempre apoyó con atención y respeto los avances de la danza mexicana y 
permitió el libre intercambio de grupos y artistas. Además, interesó a los protagonistas del movimiento a rastrear en la historia y las costumbres de México en provecho del nuevo género que a partir de 1940 se aclimataba brillantemente en el país y que ya recibía el nombre de danza moderna. Así, sus enormes conocimientos en torno al arte popular y a la historia y a la cultura de México coadyuvaron a la incorporación de esos elementos a la imaginación e inventiva de coreógrafos y bailarines. Covarrubias tenía una visión, avanzada para su época, de la forma en que deberían ser asimilados los elementos mexicanos o mexicanistas en la danza moderna. A él se deben las principales críticas a

un concepto popular de la danza prehispánica formado a través de la interpretación romántica y falsa del indigenismo porfiriano, de los carteles de mercaderías con nombres indígenas, de los festivales escolares y los espectáculos oficiales, un concepto totalmente mistificado, de un gusto ramplón y operático...

Exigía, de aquellos que frecuentaban el espíritu prehispánico para elaborar coreografías, que hicieran el "... esfuerzo por adentrarse en el espíritu místico y esencialmente rítmico de la danza indígena como la describen los cronistas".

A partir de 1950 el joven bailarín y maestro Xavier Francis, norteamericano, recién llegado, comienza a impartir cursos en la Academia Mexicana y en el Ballet Nacional de México. En la primavera de 1951 se organiza una magna temporada en la que participan el Ballet Mexicano, miembros de la Academia de la Danza Mexicana y del Ballet Nacional. Como artistas huéspedes José Limón, Pauline Koner, Luchas Hoving y Betty Jones. Puede afirmarse que el personal completo de la danza mexicana se hallaba presente en un extenso programa-repertorio compuesto por doce obras: Los cuatro soles, Diálogos, Tonantzintla y La pavana del moro (coreografías de José Limón), Imaginerias (coreografía de Xavier Francis), La manda (de Rosa Reyna), Suite de danzas y Fecundidad (de Guillermo Keys Arenas), Recuerdo a Zapata (Guillermina Bravo), La tertulia (Lucas Hoving), El renacuajo paseador (Martha Bracho), La luna y el venado (Ana Mérida). La enorme nómina dancística que proporcionó esta brillante temporada se concentraba en Los cuatro soles, coreografía monumental, exagerada y poco exitosa de José Limón, en la que en un puesto o en otro, desempeñando papeles principales o secundarios, en el centro o a los lados del 
enorme y funcional escenario del Palacio de Bellas Artes, bailaron todos los artistas que en aquel momento formaban las compañias profesionales o semiprofesionales de la danza mexicana. Mayores éxitos fueron Tonantzintla, La manda, Recuerdo a Zapata, El renacuajo paseador y La luna y el venado, las cuales retomaban el florilegio de comportamientos y leyendas indígenas para ofrecerlo a un público ávido de obras con temas nacionales.

Durante los años subsecuentes, hasta 1960, la danza mexicana adquiere renombre a través del Ballet Nacional de México y del Ballet de Bellas Artes. Asimismo otros conjuntos como el Ballet Mexicano y el Ballet Bonampak hacen florecer las características nodales de una danza que por así decirlo había surgido de su misma entraña en 1940 , dueña de un mínimo de recursos técnicos pero de un enorme caudal de talento y eficiencia; una danza que en sus primeros pasos era de esencia nacional, local, y de alcances universales; que llega a brillar con aplomo y seguridad durante quince años consecutivos, hasta la primera mitad de los años cincuentas, época en la que adquiere una nueva consigna: la danza moderna mexicana debe ser de esencia universal y de alcances nacionales o locales.

Precisamente será la intervención de otros cuadros técnicos, de maestros extranjeros y nacionales que comienzan a preparar a los bailarines maduros y a las nuevas generaciones, la que marcará el inicio de una nueva época de la danza mexicana. Esta etapa puede definirse porque surge una necesaria actitud de búsqueda y de asentamiento técnicos. Durante más de quince años, en el lapso 1939-1955, la "personalidad" de la danza mexicana se había definido notablemente mediante el impulso mexicanista y expresionista. Habían surgido talentosas figuras de la coreografía y de la interpretación y muchos otros creadores (músicos, escenógrafos, escritores) les habían brindado su apoyo. No habían sido evidentes las limitaciones técnicas porque el movimiento se apoyaba fundamentalmente en los signos de nacionalidad y de creatividad que como conjunto forjó la cultura mexicana de la época. La misma situación política y social esgrimía parámetros, si no únicos, si rígidos o hasta dogmáticos. No obstante la gran variedad de sus temas, historias, tramas, ofrecimientos y proposiciones, el Movimiento Mexicano de Danza Moderna vino a definir su "estética", la cual quedó conformada y concentrada en una obra que resume "los elementos esenciales que debieran regir a los coreautores mexicanos en sus creaciones: 
hondura y humanidad en el tema; simplicidad en su realización; perfección y claridad en la estructura dinámico-musical y en la secuencia coreográfica, y todo ello tratado con medios artísticos y técnicos cercanos a la tierra y al hombre de México": ${ }^{28}$ Zapata, coreografía de Guillermo Arriaga (1955). Dicho lapso también ha sido testigo del surgimiento de un enorme espectro de coreógrafos y obras que cabalmente conforman lo que se ha denominado movimiento de la Danza Moderna Mexicana: Guillermina Bravo, Ana Mérida, Evelia Beristáin, Rosa Reyna, Raquel Gutiérrez, Beatriz Flores, Martha Bracho, Guillermo Keys, Josefina Lavalle, Elena Noriega, John Sakmary, Raúl Flores Canelo, Carlos Gaona, etcétera.

En las postrimerías de la década de los cincuenta muchos de los protagonistas de la danza moderna mexicana realizan un viaje por Europa, la Unión Soviética y China. Constituye todo un acontecimiento que tiene lugar en 1957-1958:

La cosa es que hubo un Festival de la Paz en Moscú y se tenía muchísimo interés en la danza social y política y en el mundo socialista. $\mathrm{Y}$ jalé a todo el mundo, no sólo bailarines. Un grupo entero se fue conmigo y con Ballet Nacional. No sólo el Ballet Contemporáneo sino gentes de diversas actividades artísticas. Fueron conmigo Rafael Elizondo, Sergio Magaña, Emilio Carballido, Pepe Cava, Mario Orozco Rivera. En fin, éramos un grupo de cuarenta y tantas gentes. No sólo bailarines. Dagoberto Guillomin, Pepe Solé, directores. Casi todo México... Llevábamos un gran repertorio. Uno, el del Ballet Contemporáneo, con sus mejores obras: La manda, Tierra, Los gallos: cosas que se habían hecho en el ballet oficial de Covarrubias y que ya ido Covarrubias continuaban siendo ofrecidas en un grupo que se llamaba Ballet Contemporáneo dirigido a veces por Elena Noriega, a veces por Rosa Reyna. Por ejemplo, en el Transiberiano nos daban golpes de estado a cada rato y llegaba a mi dormitorio Elena Noriega y me decía: "El grupo ya me escogió de directora." A las tres horas llegaba Rosa Reyna: "Ya tumbamos a Elena Noriega y yo soy la directora." En fin, un grupo todavía un poco informe; sin embargo al mismo tiempo iba Ballet Nacional con su propio repertorio. A veces se mezclaban los repertorios y salían programas muy bonitos. Las mismas gentes que iban de chinches hacían también sus numeritos. Sergio Magaña y Orozco Rivera cantaban en la guitarra con gran éxito; Carballido hacía frente a todos los speeches en chino, en ruso, en italiano; sucedía en todos los lugares

28 Raúl Flores Guerrero, op. cit 
a los que llegábamos. Todos los viajeros iban con una tarea y se asimilaban a lo que había qué hacer. ${ }^{29}$

Además de la divulgación de las obras del repertorio de la danza moderna mexicana, conseguida con creces, el viaje de los bailarines mexicanos significó el enfrentamiento con otras técnicas, otros tipos de público y distintas formas de organización profesional. En efecto, los artistas mexicanos pudieron observar y analizar algunas formas de organización más rígida como las de Ballet Bolshoi y de la Opera de Pekín. Percibieron los afanes de profesionalización que caracterizan a sus integrantes desde que, muy niños, ingresan en las escuelas de danza. Asimismo, se percataron de la necesidad de la existencia paralela de centros de entrenamiento que adiestren adecuadamente a los cuadros dancísticos y coreográficos de una compañia profesional. Por último, se dieron cuenta de que resulta indispensable elaborar programas de enseñanza coincidentes con los objetivos técnicos, artísticos y sociales que caractericen a una compañía profesional.

A su regreso a México, los artistas habrian de concentrar sus tareas en la consecución de los objetivos observados: se multiplican los centros de enseñanza y se pone énfasis en el desarrollo técnico. Por estas fechas se presentaba por primera vez el Ballet Concierto, grupo de danza clásica auspiciado por Bellas Artes y dirigido por Felipe Segura y Sergio Unger. ${ }^{30}$ Asimismo, en 1957 se crea el Nuevo Teatro de Danza bajo la dirección de Xavier Francis y con la colaboración de John Fealy y Bodyl Genkel.31 Este centro privado de danza moderna funcionará hasta 1962. También en las postrimerías de los cincuenta surgen obras de Farnesio de Bernal (Cazadores, Quinteto) y Josefiña Lavalle (Juan Calavera). Anna Sokolow visitará, como maestra y coreógrafa, al nuevo Ballet de Bellas Artes y los gxupos y bailarines mexicanos programarán nuevas visitas al extranjero.

El año de 1959 cerró una década de actividad específica de la danza

29 Guillermina Bravo a Alberto Dallal: Entrevista, 1974, Inédita.

$30 \mathrm{En}$ las postrimerfas de 1956 presentan: Variaciones románticas, Serenata, Tragedia en Calabria, Mascarada, Fuego muerto, La noche de Walpurgis (coreografias de Sergio Unger), Los dos amores (Jorge Cano), Huapango y El mercado (Gloria Contreras).

31 En una temporada ofrecen al público: El muñeco y los hombrecillos, El advenimiento de la luz, Debate, Procesiones, Contrastes (coreografías de Xavier Francis), Octeto (John Fealy), Delgadina (Genkel). 
mexicana pero también apuntaba un cambio de rumbo. Según informaba John Fealy en una revista norteamericana, ${ }^{32}$ la bellísima Ana Cardus acababa de regresar con su partenaire Jorge Cano de El Salvador y se reunía con la gran Laura Urdapilleta, una de las mejores bailarinas que ha tenido el país, para presentarse en Houston, Texas. Por su parte, Xenia Zarina ofrecía conciertos con sus sui generis y hasta extrañas piezas, al mismo tiempo que en el Auditorio Nacional actuaban el grupo del Nuevo Teatro de Danza y el Ballet de Bellas Artes. Impresionaban unas Estampas de la Revolución que ofrecian en conr junto los alumnos de la academia. En Bellas Artes el mismo francés Marcel Marceau deleitaba al público con un arte muy cercano a la danza.

Una vez iniciada la década de los sesentas, los acontecimientos dancísticos parecen sucederse con fluidez y hasta con aceleración peligrosa. La Revolución Cubana atrae a muchos artistas mexicanos que viajan a La Habana a coadyuvar al desarrollo artístico del pais hermano. Entre otros, Waldeen y su esposo, el director de teatro Rodolfo Valencia. Elena Noriega se desplaza a Cuba para aplicar algunas de sus más destacadas teorias en torno a la creación. Cada uno en su campo, ofrecerán aptitudes y puntos de vista fructiferos para apoyar la labor de los cubanos. Lo mismo hará Rodolfo Reyes quien intentará acercar la danza moderna a las raíces autóctonas y al folklore. En 1960 la compañía oficial de danza mexicana toma parte en el Primer Festival Internacional de Ballet que tiene lugar en La Habana.

El auge y la operatividad de los medios masivos en México se hacen evidentes durante los primeros años de la década. La televisión ha atraido ya a las grandes estrellas de la música y de la danza populares, sobre todo en sus modalidades urbanas. Prolífica, estruendosa, apetitosa, autogestiva y universalmente aceptada, la danza popular urbana de México conserva por aquellos años su consistente autenticidad ante el embate de ritmos y figuras provenientes del extranjero. El rock y Los Beatles comienzan a hacer chuza en los hábitos dancísticos de la clase media, pero el dancing, sus espacios, sus tinglados y sus implicaciones ${ }^{33}$ protegen de tal manera al danzón, la guaracha, el mambo, el

32 Dancemagazine, diciembre de 1959

33 Para una descripción y una interpretación pormenorizadas del fenómeno, véase Alberto Dallal, El "dancing" mexicano. 
cha-cha-cha y hasta el tango y el pasodoble que aún en la actualidad y con renovados bríos estos y otros ritmos se hallan vigentes. A partir de los sesentas se comprobará la enorme habilidad recreativa de los chavos y chavas de la clase media: no hay ritmo extranjero del que no se apropien para superar códigos, coreografías, interpretaciones. Ante el decaimiento de la danza teatral culta, las nuevas generaciones hacen florecer, vía la danza popular urbana, las manifestaciones de sus movimientos y cuerpos. Las proposiciones formales de estos sectores destacan notablemente toda vez que la danza moderna, incluso en los Estados Unidos, sólo posee ofrecimientos experimentales. Años de anunciación y de intensa observación, los primeros sesenta encauzan las energías de la juventud en todo el mundo hacia lo que en los últimos sesenta será un abierto brote de rebeldía, fenómeno social que aun reprimido, liberará tanto a las nociones y a la cultura del cuerpo como al cuerpo mismo y sus expresiones artísticas.

Por estos años se disuelven dos importantes centros de enseñanza: el Ballet de la Universidad de Magda Montoya (surgido diez años antes) y el Nuevo Teatro de Danza. Sintomáticamente, en contraste con las repeticiones coreográficas de la mayoría de los grupúsculos y compañías de danza moderna, destacan las que durante muchos años serán las figuras cimeras de la danza clásica mexicana: Laura Urdapilleta, Nellie Happee, Sonia Castañeda, Gloria Contreras, Tulio de la Rosa, Jorge Cano, Francisco Araiza. Algunos de ellos llevan la misma trayectoria: discípulos de Madame D'Ambré, anteriormente atentos alumnos de las Campobello y sólidos y considerados amantes de un género poco arraigado al suelo mexicano. Por aquella época ya figura en el extranjero la luminosa presencia de Lüpe Serrano, ex alumna de la Academia de la Danza Mexicana, compañera de esos jóvenes bailarines que sostuvieron a la danza clásica mexicana durante varias décadas: Felipe Segura, Armida Herrera, Socorro Bastida, Carolina del Valle, Guillermo Keys Arenas, Roberto Iglesias. A esta pléyade pertenece Lupe Serrano, quien en 1951, "sin ningún contrato, sin ninguna seguridad económica, casi sola se lanza a un juego con la suerte" en Nueva York, e ingresa en el Ballet Ruso de Montecarlo para más tarde desembocar en el Ballet Theatre. Doce de los más importantes años de su vida habían transcurrido en un México en plena conformación artística. En alguna de sus visitas revela su idea sobre nuestras danzas autóctonas: 
Sí: son dignas de la mayor admiración y pueden ser fuente de inspiración para los coreógrafos. Pero no hay que olvidar que su mayor encanto, su más trascendental valor palpita en el hecho de su tradición y de su pureza. Si tratamos de cambiarlas, de modificarlas, de hacerlas modernas, pierden su auténtico prestigio. ${ }^{34}$

En los sesentas ocurre también una especie de simbiosis entre la danza clásica y la danza moderna: algunos de sus protagonistas unen fuerzas para presentar espectáculos conjuntos (Ballet Contemporáneo, Danza de Cámara) o para organizar festivales y "talleres" en lo que se intenta difundir la enseñanza de ambas técnicas. Algunas de las figuras importantes de la danza mexicana comienzan a abrir establecimientos particulares en donde muestran las excelencias de sus conocimientos y prácticas. Waldeen crea un Centro de Danza y Artes Escénicas. Ante la inquietud juvenil y estudiantil, las instituciones culturales vuelven los ojos (muchos de ellos apartados durante mucho tiempo) hacia la danza, un ejercicio vital, colectivo, comunitario lleno de sugerencias y destrezas, vigoroso y pleno "En esta época el Ballet Nacional de México y otras entidades dancísticas comienzan a recibir un mayor apoyo de las instituciones culturales. Por su parte, el Instituto Mexicano del Seguro Social se interesa por ampliar el panorama de la enseñanza de la danza folklórica que había apoyado durante muchos años y llama a otros bailarines para dar a conocer la danza moderna y la danza clásica. Ingresan como maestros, entre otros, Tulio de la Rosa, Helena Jordán y Nellie Happee.

La crisis social y cultural de la época también se va a reflejar en notables y sucesivas escisiones dentro de los grupos profesionales de danza moderna, género que en aquella época se va convirtiendo precisamente en danza contemporánea. Raúl Flores Canelo y Gladiola Orozco inician las actividades del Ballet Independiente, abandonando el ideario y las prácticas del Ballet Nacional de México de Guillermina Bravo. Ésta será sólo el anuncio de una serie sucesiva de escisiones que en México, como en todo el mundo, hacen surgir grupos y compañías de danza por bi y pluripartición. Expansión Siete (1973), Mórula (1975), Forion Ensamble (1977), Ballet Teatro del Espacio (1979). Aun resonando los ecos y las intensidades del movimiento estudiantil de 1968, la Olimpiada cultural permite en México la actua-

34 Folleto publicado con motivo de su visita a México con el Ballet Theatre, s/f. 
ción del Ballet del Siglo XX de Maurice Béjart y de un Ballet de los Cinco Continentes organizado por Amalia Hernández, directora del Ballet Folklórico de México, la compañía profesional privada de danza profesional más grande y conocida que ha habido en México.

Durante esta década surgen y se desarrollan nuevos coreógrafos en el ámbito del Ballet Nacional de México. Rossana Filomarino, Federico Castro, Luis Fandiño. Callada pero imperturbablemente el grupo asimila la técnica Graham mediante múltiples viajes a Nueva York y gracias a la visita de maestros como David Wood, Yuriko, Kasuko Hirobayashi, etcétera. La acción creativa de Bravo supera su etapa mágico-indígena, la inserta en un periodo "didáctico-intelectual" (no exento de cierta retórica) y la hace buscar una expresión más limpia que reconsidera, por una parte, la línea expresionista (Montaje, Melodrama para dos hombres y una mujer) y, por la otra, un claro y equilibrado simbolismo (Amor para Vivaldi, Apunte para una marcha fúnebre, Juego de pelota, Interacción y recomienzo). Hasta 1968 Ballet Nacional de México preparaba a sus cuadros dancísticos mediante un esfuerzo inaudito de convencimiento y búsqueda, sorteando los avatares de la ausencia de jóvenes interesados en la danza mediante la incorporación de elementos que por sacrificio, vocación indiscutible y convicción plena aceptaban profesionalizarse como bailarines. En 1969 el Ballet Nacional de México inicia los trabajos de un centro que habría de preparar a bailarines y coreógrafos provenientes del mundo estudiantil (o sea de la clase media), a partir de una edad adecuada y con el proyecto de dedicarse profesionalmente a la danza. Con la colaboración de la Dirección General de Difusión Cultural (en aquel entonces comandada por Gastón García Cantú) de la Universidad Nacional Autónoma de México se organiza el Primer Curso Intensivo de Danza Moderna. Las clases cotidianas y profesionales de este proyecto se completaban con charlas, conferencias y experimentos que ampliaban el horizonte de los jóvenes estudiantes, los cuales habían sido previamente seleccionados. Con el tiempo, y más tarde bajo la direa ción de Lin Durán (experimentada ex bailarina de la compañía), el curso asumirá el nombre de Seminario de Danza Contemporánea y Experimentación Coreográfica y la misma maestra trasladará los conocimientos adquiridos y los renovados programas hacia la Escuela de Perfeccionamiento Vida y Movimiento, que diez años más tärde de- 
vendrá primera escuela oficial de danza contemporánea cabalmente organizada.

Surgido como bailarín y coreógrafo en el Ballet Nacional de México, Raúl Flores Canelo fundó en 1966 el Ballet Independiente, compañía que se significó desde entonces por su afán de búsqueda y por sus intentos de unir temas netamente mexicanos y sociales (característica del Movimiento Mexicano de Danza Moderna) con las tendencias más recientes de la danza contemporánea, A partir de una escisión sufrida en 1979, la compañía se denomina Compañía de Danza de Raúl Flores Canelo. Este serio y disciplinado creador ha permanecido fiel a sus búsquedas. En el actual repertorio de la compañía destacan sus obras: Queda el viento, Jaculatorias, De aqui, de allá y de acullá.

Luis Fandiño surge en el Nuevo Teatro de Danza donde trabaja durante varios años brillantes con Francis, Fealy, Genkel, Reyes y otros bailarines. Más tarde, Fandiño ingresa en el Ballet Nacional de México y produce obras inquietantes: Caleidoscopio (1967), Metrópoli (1969), Serpentina (1970), Operacional I (1972) y Operacional II (1974). Estas y otras coreografías de Fandiño muestran al creador de una línea de "exposición" directa y pura de los movimientos y de las formas en danza. Fandiño busca atmósferas, espacios, relaciones, más que "figuras" (que en algunos casos de la danza contemporánea llegan a ser escultóricas o acrobáticas). Para Fandiño, el cuerpo humano posee una naturalidad que una vez transgredida contradice o violenta a la naturaleza misma de la danza. Los movimientos, en sus piezas, fluyen, exponen, descubren, revelan, llegan a "ser" gracias a la fluidez con la que los elementos (cuerpos, diseños, formas, espacios, contenidos) se êtrtectũzann, sê uneñ y separân, sê hacen síntesis. Resulta difícil que el espectador se aparte de la danza misma para atender a una anécdota. Verdaderamente abstractas, algunas piezas de Fandiño, como Serpentina, impresionan por su sencillez y simultáneamente por su complejidad y por la presencia de una inigualable cadena de imágenes y signos: elementos por medio de los cuales el espectador "pensará" en algo, suscitado sólo por las imágenes: niñez, amor, pureza, muerte, placer, inmediatez, adolescencia. En Metrópoli, por ejemplo, se experimentan varios tipos de relación humana: dos, tres, cuatro individuos y este llamémosle examen de situaciones produce formas cuyo sentido llega al público dancísticamente sin las obviedades de una descripción literal. La capacidad de abstracción de Fandiño culmina en Serpentina, 
obra para la que el coreógrafo creó una música de "ruidos" y ritmos funcionales. Los Operacionales llevan la capacidad de experimentación de Fandiño hasta sus últimas y más brillantes consecuencias. Son obras en las que el coreógrafo aplica la técnica de la improvisación estableciendo parámetros previos: estados de ánimo, embriones de movimiento, numeraciones, etcétera, Los tres "inventores", en el escenario, van ofreciendo un juego lleno de hábiles y rápidas sugerencias dancísticas; surgen bellas formas sin apartarse del rigor técnico propio de los recursos dancísticos profesionales.

Durante la década de los setentas se hace más alaro el panorama: se asientan proyectos, tendencias y técnicas. Ya en 1970 resulta obvia la necesidad de reorganizar un arte que a todo el mundo atrae y que mucho sintetiza todas las inquietudes sociales, culturales y hasta ar-tísticas del hombre contemporáneo. Esta necesidad está dictada y se manifiesta a partir de una incontrolable búsqueda de la danza en todos los ámbitos de la población. Se exigen centros de aprendizaje, espectáculos, programas de televisión, publicaciones, orientación vocacional. En muy pocas instancias de la danza mexicana se cumplen los requerimientos de tan vasta proyección. Gracias a los núcleos serios, pensantes y organizados van multiplicándose los conductos, los centros, las posibilidades. Pero se hace lentamente. Algunos programas y trabajos se ven impelidos a apresurar su ritmo de indagación y de realización. Se pone a prueba la preparación real de muchos bailarines, coreógrafos, organizadores, críticos y funcionarios. Una serie sucesiva de instituciones señalan la importancia que adquiere la danza en México.

En 1970 Body Genkel crea un Ballet Contemporáneo muy cercano a los ámbitos oficiales de la enseñanza de la danza. La bailarina y coreógrafa Gloria Contreras inicia su Taller Coreográfico de la Universidad, grupo que en 1974 establecerá un Seminario de Iniciación para los estudiantes universitarios. ${ }^{35}$ En 1971 la Academia de la Danza Mexicana revisa a fondo sus procedimientos didácticos para adaptarlos a la nueva época y a la ya evidente mayor demanda de conductos de enseñanza y preparación. La existencia de una cambiante y poco efectiva compañia de danza clásica señala la necesidad de crear una Compañía Nacional de Danza, la cual inicia sus trabajos en 1973 para, en

35 Véase Varios autores, Taller Coreográfico de la Universidad, Difusión Cultural, UNAM, 1977. 
1975, recibir la asesoria y el apoyo totales de la Escuela Cubana de Ballet. Las compañías profesionales de danza contemporánea comienzan a realizar efectivos y a veces prolongados viajes por países extranjeros. A su vez, las mejores compañías internacionales de danza visitan México abriendo las perspectivas de comprensión y asimilación de este arte. Por momentos, la Compañía Nacional de Danza brilla esplendorosamente, sobre todo a través de Susana Benavides y las numerosas figuras extranjeras que son contratadas para cubrir la ausencia de cuadros masculinos en el ballet mexicano. Durante los primeros años de la década, la incansable Amalia Hernández abre las puertas de su Ballet Folklórico para iniciar a jóvenes estudiantes en técnicas de danza contemporánea; asimismo, apoya a otras compañías y figuras de la danza mexicana organizando presentaciones y homenajes (v.gr. el que se tributó a Guillermina Bravo en 1976). Determinante fue la creación del Fondo Nacional para el Desarrollo de la Danza Popular Mexicana (Fonadan), en 1972, que Josefina Lavalle ha mantenido funcionando como centro compilador de las danzas autóctonas y vernáculas de México. Algunos destacados bailarines y coreógrafos como Xavier Francis, Rodolfo Reyes, Luis Fandiño, Onésimo González, Carlos Gaona, Martha Bracho y Lila López se foguean como maestros y coordinadores en los trabajos de danza que requieren los distintos estados de la república: Veracruz, Jalisco, Coahuila, Guanajuato, San Luis Patosí, etcétera. En 1984 Martha Bracho cumple 30 años de trabajos ininterrumpidos en Hermosillo, Sonora. Nuevos grupos y modalidades se incorporan a ese amplio panorama que, no obstante sus notables alcances, sólo apunta en dirección de lo que podrán hacer cuadros dancísticos sólo recientemente profesionalizados.

Gladiola Orozco y Michel Descombey fundaron, a partir del Ballet Independiente, el Ballet Teatro del Espacio (1979). Por contar con el apoyo oficial desde sus primeras actividades, esta compañía se ha desarrollado profesionalmente de una manera notable. Entre sus miembros hay estupendos bailarines y jóvenes intérpretes que apuntan a figuras notables de la danza contemporánea mexicana. En su afán de búsqueda, la compañía no ha cerrado ninguna posibilidad creativa y sus sucesivos repertorios han mezclado experimentos insustanciales como La ópera descuartizada de Descombey, obras de concepción sencilla e implacable como las de Bernardo Benítes, La Malinche de José Limón (adquirida recientemente), búsquedas interesantes como las de Miguel 
Ángel Palmeros e intentos de psicoteatro como Icaro de Gladiola Orozco. El Ballet Teatro del Espacio es una organización profesional seria y sus pretensiones van acompañadas de una eficiente publicidad que ie han abierto la posibilidad de atraer un público fiel, asiduo.

Luis Fandiño abandonó el Ballet Nacional de México en 1975. Era principalísimo coreógrafo y bailarín de la compañía. Durante varios años sólo ejerció la enseñanza y a partir de 1980 se ha convertido en el director artístico del grupo Alternativa. Junto con Guillermina Bravo, Fandiño posee una de las más ricas e interesantes trayectorias creativas de la danza mexicana. Como bailarín, ordenó y precisó su propia técnica a partir de las enseñanzas de Xavier Francis, maestro norteamericano que radica en México desde 1953. Como coreógrafo ha logrado unir la consistencia teórica, la imaginación y la apertura hacia experimentos sumamente cuidados. Las danzas de Luis Fandiño impresionan por sus confecciones nítidas y por su capacidad para eludir la narración elemental y obvia mediante el tránsito hacia una cuidada abstracción o, en su caso, hacia una equilibrada simbolización. Entre las más actuales obras de Luis Fandiño destacan: En tres tiempos, Dos y Suceso-crónica.

El Forion Ensamble realizó sus primeras presentaciones a finales de 1977. Desde el principio se significó por la juventud de sus integrantes y por los planteamientos artísticos que hacían. Los miembros del Forion provenían del Ballet Nacional de México, habían recibido enseñanzas de varios maestros neoyorkinos y estaban dispuestos a ejercer en México los caminos de libertad que en los Estados Unidos transitaban ya los grupos de vanguardia. En una palabra, el Forion Ensamble proponía lo más nuevo e interesante de la danza contemporánea mexicana y a la vez lo hacía profesionalmente. Desde 1978 hasta 1981 estos jóvenes han conseguido forjar un repertorio lleno de sorpresas, no todas ellas logradas y saludables, pero siempre frescas proposiciones coreográficas que interesan como planteamientos: Bumerang y Nadie me quiere asi de Jorge Domínguez, Tercera persona de Lidia Romero y Sucesión e Intersección de Eva Zapfe. Asimismo, el Forion llevó a cabo experimentos novedosos como danzas al aire libre, performances y happenings en el Museo de Arte Moderno de México y otras experiencias no tan felices como la incorporación de la danza popular mexicana (guaracha, son, danzón, etcétera, a espectáculos "populares" rápidamente estructurados. El Forion Ensamble, no obstante 
su corta edad, viajó por India, Cuba y otras naciones europeas y africanas.

El Taller Coreográfico de la Universidad de Gloria Contreras du* rante diez años ha expuesto ininterrumpidamente una modalidad que podríamos denominar neoclásica y que persigue los fundamentos técnicos y coreográficos de Balanchine, coreógrafo con el que Gloria Contreras trabajó durante varios años. El Taller Coreográfico no obedece a una sola línea creativa y ha incorporado a su acervo simultáneamente la música electro-acústica, la música popular, el rock, Xenaquis y obras de los jóvenes compositores mexicanos: naturalmente, estas circunstancias lo han obligado a rechazar una linea creativa constante. Aunque no se puede hablar por tanto de un estilo o de una escuela creativa, el Taller Coreográfico posee un vasto público que admira y quiere a su figura principal. Recientemente, Gloria Contreras ha incorporado en su repertorio obras que se significaron durante el Movimiento Mexicano de Danza Moderna tales como Zapata de Guillermo Arriaga y Los gallos de Farnesio de Bernal, Asimismo, en 1981 el Taller Coreográfico de la Universidad montó Concierto barroco de Balanchine. Con excepción de Gloria Contreras (y desde la salida de las bailarinas que habían trabajado con ella durante ocho años) el Taller se ha convertido en un grupo de tipo experimental en el sentido semiprofesional que posee el término. Gloria Contreras es autora de más de setenta coreografías.

Danza Libre Universitaria es un grupo creado a partir del Taller Coreográfico de Gloria Contreras. Su directora, Cristina Gallegos, ganó el Ilamado Premio Nacional de Danza en 1980. En esta compañía trabajan dos experimentadas bailarinas: Cora Flores y Aurora Agüeria. Sus principales obras son: Adagio, Prólogo, Dueto, Trio.

En dos ciudades distintas de la ciudad de México, Guadalajara y Xalapa, han trabajado por varios años dos coreógrafos profesionales: Onésimo González (quien recientemente se trasladó a Veracruz), creador, entre otras coreografías de: Eco y agua y Conflicto; y Rossana Filomarino, nacida en Italia, quien tuvo a su cargo durante cinco excepcionales años la Compañia de Danza Contemporánea de la Universidad Veracruzana en la que compuso, entre otras obras: Lugar común, Icaro y Llama de amor vivo.

Tanto la ancestral inclinación del mexicano por la danza como la notable divulgación que de este arte han llevado a cabo los medios 
televisuales permiten observar en México una actividad dancística estable, variada y en muchos casos extraordinaria. No hay ningún género dancístico que no tenga en México sus creadores, sus intérpretes, sus espectadores. En efecto, México es un país de danzantes. No sólo lo que el pais ha hecho en danza durante muchos siglos representa múltiples temas de interés y de investigación. Podemos afirmar que lo que en este preciso instante se hace de danza en México ofrece puntos de interés estético, social, histórico suficiente para aquellos que observan con atención y esmerado criterio la multiplicidad de actividades dancísticas que en el país se realizan. 